\title{
Sapropelis un tā izmantošanas iespējas
}

\author{
Karina Stankeviča ${ }^{1}$, Māris Kḷaviņš ${ }^{2},{ }^{1-2}$ Latvijas Universitāte
}

\begin{abstract}
Kopsavilkums. Sapropelis ir ar organiskajām vielām bagāti nogulumi, kas nogulsnējas ūdenstilpēs. Sapropẹ̦a izplatība un plašas izmantošanas iespējas padara to par nozīmīgu dabas resursu, ko var izmantot lauksaimniecībā, dārzkopībā, mežsaimniecībā, lopkopībā, ķīmijas un celtniecības industrijā, balneolog̣ijā un kosmetolog̣ijā. Kopējie sapropeḷa resursi Latvijā sastāda aptuveni 2 miljardus $\mathbf{m}^{3}$. S̄ī raksta mērḳis ir aplūkot sapropeḷa klasifikāciju, veidošanās apstākḷus un izmantošanas jomas.
\end{abstract}

Atslēgas vārdi: sapropelis, gitija, ezeru nogulumi, organiskais mēslojums, ārstnieciskās dūṇas, būvmateriālu izejvielas.

\section{IEVADS}

Latvijā ir 2256 ezeri ar kopplatību $1001 \mathrm{~km}^{2}$ jeb 1,5\% no Latvijas teritorijas [1], purvu kopplatība ir $6401 \mathrm{~km}^{2}$ jeb $9,9 \%$ valsts teritorijas [2]. Lielākajā daḷā šo ezeru un purvu (zem kūdras slāņa) ir sastopams sapropelis - izmantojams, dal̦ēji atjaunojams zemes dzịlı resurss, kas ir kvartāra periodā veidojušies organiski nogulumi, kuri uzkrājas, nogulsnējoties atmirušo ūdensaugu un dzīvnieku atliekām, sajaucoties ar minerālvielām.

Sapropelis ir plaši izplatīts visā pasaulē. Visintensīvākā sapropel̦a veidošanās un uzkrāšanās ir raksturīga Āzijas un Eiropas mērenajai klimata joslai (Krievija, Skandināvijas pussala, Francija, Vācija, Polija, Baltijas valstis, Baltkrievija un Ukraina) un Ziemel̦amerikas kontinenta Lielo Ezeru reǵionam (Kanāda un Amerikas Savienotās Valstis).

Latvijas ezeros aplēstais sapropeļa daudzums, ko novērtējis Valsts ǵeoloǵijas dienests, pamatojoties uz Latvijas ezeru

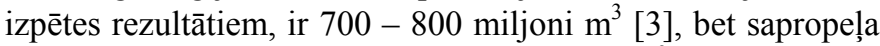
krājumi purvos sasniedz 1,5 miljardus $\mathrm{m}^{3}$ [4]. Kopējie sapropel̦a resursi Latvijā sastāda aptuveni 2 miljardus $\mathrm{m}^{3}$.

Sapropeḷa resursu daudzums un tā plašās izmantošanas iespējas padara to par valsts mēroga stratēgisku dabas resursu; tā pārstrādes produktus var eksportēt visā pasaulē. Lauksaimniecībā, dārzkopībā un mežsaimniecībā to izmanto augsnes mēslošanai un augsnes uzlabošanai, lopkopībā tas kalpo kā piedeva dzīvnieku barībai, tas ir arī piemērots izejmateriāls k̦īmijas un celtniecības industrijai, arī kā ārstniecisks līdzeklis medicīnā - ārstnieciskās dūṇas, izejviela koagulantu ražošanai.

Latvijā sapropelis līdz šim tika izmantots galvenokārt lauku mēslošanā. Sapropeḷa pētniecības un izmantošanas krīze Latvijā sākās 1993. gadā. Tā ieguve nelielos daudzumos notika tikai Spīgu purvā, kur AS „Dobele” izmantoja sapropeli lopbarības, kompleksā mēslojuma, komposta un līmvielu ražošanai [3]. Sapropel̦a rūpnieciska ieguve un izpēte atsākās tikai 2008. gadā, tomēr tās apjomi vēl joprojām ir niecīgi. Galvenokārt tas ir saistīts ar nepietiekamu sapropel̦a pieprasījumu pasaules un Latvijas tirgū, cilvēku vājo informētību par sapropeḷa izmantošanas iespējām un nepietiekamo izpētes līmeni.

Ezeri ir nozīmīgs saldūdens resurss, tie ir vērtīgi dabas elementi un savā zin̄ā ir svarīgi arī kā valsts ekonomikas sastāvdaļa. Tos izmanto modernajā zivjkopībā, medību saimniecībās, hidroenerǵêtikā, kā dažādu ūdens sporta veidu praktizēšanas vietas, izklaides un kultūras nolūkos. Tāpēc aizaugušo ezeru atvesel̦ošana ir svarīgs priekšnosacījums ilgtspējīgas dabas resursu apsaimniekošanas politikas realizēšanai [5].

Dabas resursu izmantošanai ir jābūt videi nekaitīgai un efektīvai. Radot inovatīvus produktus ar augstu pievienoto vērtību - videi draudzīgu, netoksisku, ar spēju saistīt smagos metālus - ir iespējams ievērojami samazināt izdevumus saldūdens attīrī̌sanas un saglabāšanas pasākumiem ar augstu potenciālu ilgtspējīgai turpmākai ezeru izmantošanai tautsaimniecīibā.

\section{SAPROPEL̨A VEIDI UN KLASIFIKĀCIJA}

Sapropelis ir sīkgraudainas un irdenas nogulsnes, kas ir bagātas ar organiskajām vielām un kas nogulsnējas ūdenstilpēs. Petroloǵijā par sapropeḷa oglēm apzīmē nogulumus, kas veidojas ūdens vidē no makrofìtu atliekām. Termins sapropelis bieži tiek izmantots, apzīmējot ar organisko oglekli bagātus, tumšas krāsas sedimentus [6].

Šaurākā nozīmē sapropelis (grieķu val. „sapros” sapuvis + „pelos” dubļi) ir mūsdienu vai subfosīlie, koloidālie kontinentālo ūdenstilpju nogulumi ar smalku struktūru, kas satur nozīmīgu organisko vielu daudzumu un mikroskopisko ūdens organismu atliekas ar nelielu neorganisko biogēnas izcelsmes komponentu saturu un minerālo ingredientu piejaukumu [7], kas var būt - smilts, māls, kalcija karbonāts un citi ieži [8].

1. TABULA

GALVENĀS ATŠĶIRĪBAS STARP KŪDRAS UN SAPROPEḶA İPAŠĪBĀM

\begin{tabular}{|l|l|l|}
\hline Rādītāji & Sapropelis & Kūdra \\
\hline Veidošanas vide & nosacīti bezskābekḷa & bezskābekḷa \\
\hline Vides reakcija, $\mathrm{pH}$ & neitrāla & skāba \\
\hline Organiskās vielas, \% & $15-85$ & $>50$ \\
\hline $\begin{array}{l}\text { Organisko vielu } \\
\text { veidotāji }\end{array}$ & $\begin{array}{l}\text { ūdens organismi: } \\
\text { fitoplanktons, } \\
\text { zooplanktons, augstākie } \\
\text { ūdens un piekrastes augi }\end{array}$ & $\begin{array}{l}\text { purvu augi: lapu } \\
\text { un skuju koki, } \\
\text { krūmāji, zālaugi, } \\
\text { sūnas }\end{array}$ \\
\hline
\end{tabular}

Sapropelis veidojas nosacītā bezskābekḷa vidē, fizikālķīmisko un bioḳīmisko ezera hidrobiontu pārvērtību rezultātā ar dažādu minerālo un organisko vielu līdzdalību terigēnā (latīṇu val. terrigenus - zemes radīts) notecē. Dažādu atradņu sapropel̦a sastāvs un īpašības ir l,oti atškirīgas; ko nosaka konkrētās ūdenstilpes produktivitāte, virszemes 
noteces īpatnības un klimatiskie apstākḷi. Par sapropeli pieñemts uzskatīt saldūdens nogulumus ar organisko vielu sastāvu lielāku par 15\%, pretējā gadījumā šie nogulumi tiek uzskatīti par augsti pelnainiem ezera nogulumiem [7].

No kūdras sapropelis atšķiras (sk. 1.tabulu) ar smalku struktūru, vides reakciju, organisko vielu daudzumu un tā veidotājorganismiem un humusvielu daudzumu [7], [9].

Vienotu terminu un klasifikācijas izveidošana ezeru nogulumiem ir apgrūtinoša, jo katra zinātne ir izveidojusi savu terminologiju un klasifikāciju, kas atbilst tās pētījumu virzienam un mērķiem [10] - [12]. Tā E. Tomins un A. Fomins 1964. gadā izstrādāja sapropel̦a klasifikāciju [13], kas ir balstīta uz sapropel̦a bioloǵisko komponentu sastāvu. Šo klasifikāciju, pārveidojot Latvijas ezeru organisko nogulumu īpašību izvērtēšanas kritērijus (sk. 2.tabula), izmantoja R. Alksnī̌̌a vadībā veiktajos sapropel̦a atradṇu meklēšanas darbos, kas ilga no 1990. gada līdz 2000. gadam [14].

Zinātniskā interese par ezeru organiskajiem nogulumiem radās vairāk nekā pirms 100 gadiem. 1862. gadā ezera nogulumus pēc to izcelsmes 2 lielās grupās iedalīja G. Postons: „gyttja” - autohtonie nogulumi un „dy” alohtonie nogulumi. Vēlāk vācu zinātnieks R. Lauterborns paplašināja

2. TABULA

SAPROPEL̨A KLASIFIKĀCIJA [14]

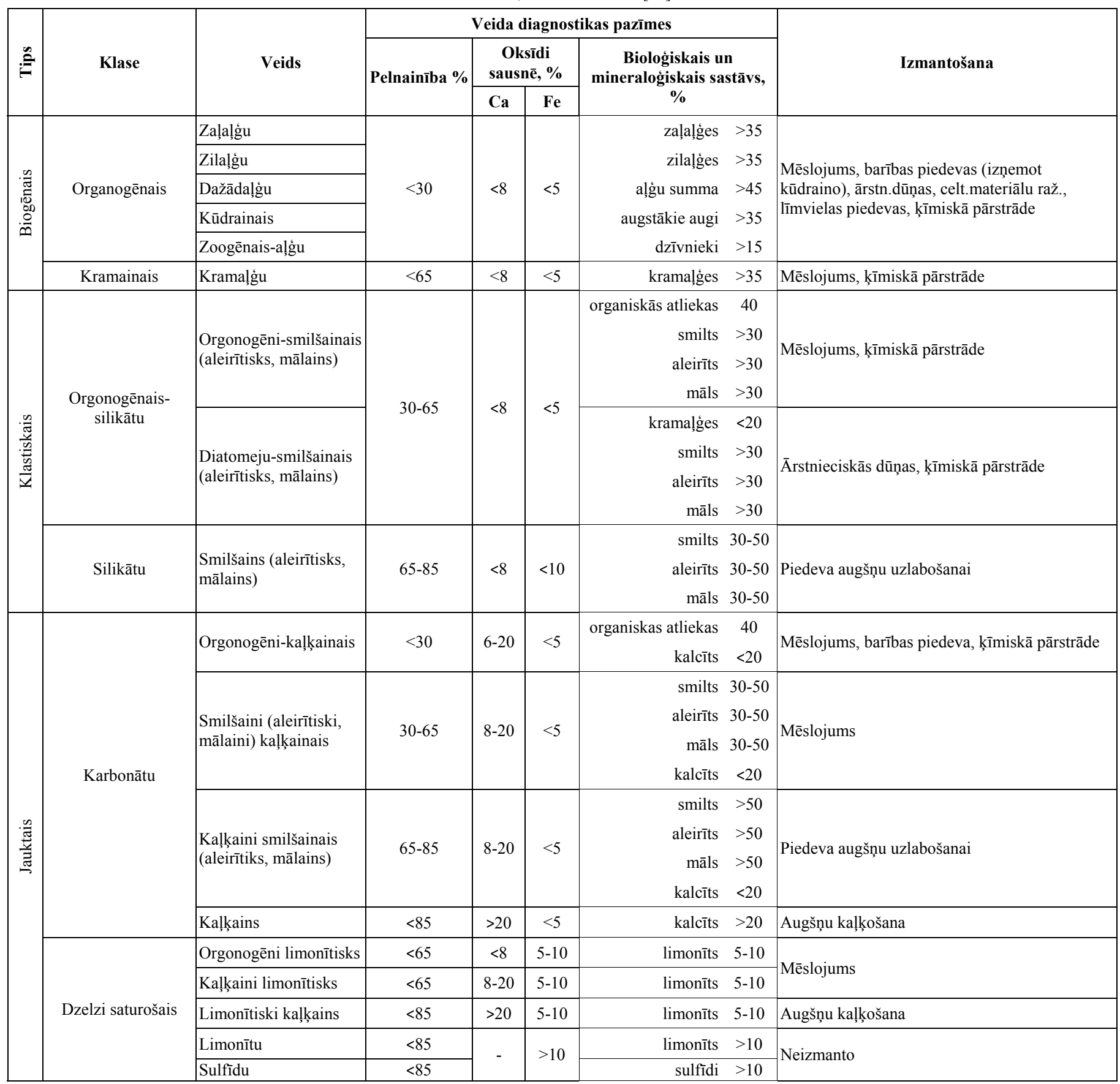


šo klasifikāciju ar vēl vienu grupu „sapropelis” - nogulumi ar sērūdeņraža smaržu [15].

Atkārtoti, ar mūsdienu izpratni, terminu ,sapropelis” ieviesa G. Potenje. Klasificējot ezeru nogulumus, G. Potenje izdalīja divas grupas: „sapropelis” - viskozas, smalkdispersas, 25 $90 \%$ organisko vielu saturošas nogulsnes, un l̦oti mineralizētas nogulsnes - „sapropelīti”, kurus viņš iedalīja sīkāk pēc to minerālajiem komponentiem: diatomīta, kal̦ka, dzelzs un smilts [16].

N. Korde 1960. gadā sapropeli iedalīja divās grupās, vadoties no organisko vielu satura: „sapropelis” satur vairāk nekā $50 \%$ organisko vielu un ,ar organiskām vielām nabadzīgs sapropelis", kas satur $15-50 \%$ organisko vielu. Šìs grupas, izmantojot hidrobiontu atlieku bioloǵisko analīzi, vina klasificēja sīkāk: kramal̦íg (Diatoma), zal̦alğ (Chrysophyceae), zilal̦ǵu (Cyanophyceae) un zoogēnais sapropelis [7].

A. Pidopl̦ičko un R. Grišuka sapropel̦a klasifikācija ir detalizētāka un tiek izmantota visbiežāk. Ezera nogulumi tajā tiek iedalīti 7 tipos [17]:

- mālains sapropelis ir ar augstu pelnainību, parasti ezeros tas nogulsnējas dabiskā veidā. Tas ir plastisks, smags, pelēkā vai pelēkzilā krāsā;

- kal̦kains sapropelis. Tā pelnainība ir lielāka par 35\% (tajā skaitā $50-65 \% \mathrm{CaO}$ ), iegulas veidojas ar augstu kalcija saturu gruntsūdeņu izteku vietās. Tas ir pelēkzaḷā krāsā, bet izžūstot veido nesaistītu bālgani pelēku masu;

- silikātu sapropelis ir nogulumi ar augstu pelnainību pelnu saturs tajos ir lielāks par 30\% (tai skaitā > 30\% $\mathrm{SiO}_{2}$ un $<10 \% \mathrm{CaO}$ ). Tas veidojas gala morēnu ainavās, noslēgtās ezerdobēs kā piedibena nogulumi, vai arī iegul virs mālaina sapropel̦a slāņa, virs kura parasti atrodas organiskā sapropel̦a slānis. Silikātu sapropelis ir pelēkzal̦š vai zaļš ar smilšu graudiniiem un tumši krāsotām, blīvām dzīslām;

- jaukta tipa sapropelim ir loti augsta pelnainība (ap 70 $80 \%$ ), tas var saturēt lielu kalcija un silikātu daudzumu, silikātu un māla vai mālainās dal̦iņas un kalciju, kā arī visus trīs komponentus ar organiskiem ieslēgumiem. Šie jauktie ezera nogulumi ir veidojušies no planktona organismiem. Minerālu pieplūdes avots šim sapropel̦a tipam var būt grunts un diluviālie jeb nogāžu ūdeñi. Tas var būt pelēcīgā, tumši zaḷā, zilganzaḷā vai pelēcīgi brūnā krāsā;

- organiskais (smalka detrīta) sapropelis ir sapropelis ar zemu pelnainību, kas nepārsniedz 30\%. Tam ir zaļa krāsa, ar humusvielu piejaukumu - zal̦i brūna. Organiskais sapropelis rodas ūdenstilpēs, kurās nav lieli minerālo vielu pieplūdes avoti;

- rupja detrīta sapropelis ir ar zemu pelnainību. Tas uzkrājas ezeros, kur bez planktona organismiem aug daudz augstāko ūdensaugu, kuru atliekas lielos daudzumos saglabājas sapropelī. Šāds sapropelis parasti ir tumši zal̦ā krāsā un tajā var saskatīit augstāko ūdensaugu palieku ieslēgumus, tas parasti nogulsnējas uz citu tipu sapropeḷa slāniem un neveido biezus slāṇus;
- kūdrains sapropelis rodas, saskaroties kūdras iegulai ar ezeru vai aizaugot seklūdens zonai eitrofās ūdenstilpēs. Tas ir sapropel̦a un kūdras starpveidojums ar brūnu krāsu un dažādu augstāko augu paliekām - niedres, grīşıli, kosas u.c. Saberžot kūdru, sapropelis nesmērējas, tam ir raksturīga l’oti zema pelnainība $(8-10 \%)$ un sadalīšanās pakāpe (ap $25-30 \%$ ). Šis sapropeḷa tips nogulsnējas nelielos slāņos starp kūdras un sapropel̦a iegulām.

Baltkrievu zinātnieki A. Pidoplıčko [18] un M. Lopotko [19], pētot sapropeli Baltkrievijas teritorijā, kā arī M. Štangebergs [7], pētot ezeru nogulumus Suval̦skas novadā, iedalīja sapropeli 4 grupās:

- silīcija dioksīdu saturošais sapropelis (pelnainība > $30 \%, \mathrm{SiO}_{2}$ saturs pelnos $>50 \%$ );

- karbonātu sapropelis (pelnainība $>30 \%, \mathrm{CaO}$ saturs pelnos $>30 \%$ );

- jauktais sapropelis (pelnainība $>30 \%, \mathrm{SiO}_{2}$ un $\mathrm{CaO}$ saturs pelnos ir aptuveni vienāds);

- organiskais sapropelis (pelnainība $<30 \%$ ).

Arī L. Kirejčeva, pētot Krievijā sastopamo sapropeli, klasificēja to 4 grupās: organiskais, jauktais, karbonātu un alumosilikātu [12].

Organiskais sapropelis ir bagāts ar organiskām vielām (7093\%), tam var būt paaugstināts skābums ( $\mathrm{pH} 3.5-6)$ un zems pelnu saturs.

Jauktajā sapropelī organisko vielu saturs ir 50-68\%, vides reakcija $\mathrm{pH} 6$, tas ir bagāts ar kalciju, fosforu, slāpekli un mikroelementiem.

Karbonāta un alumosilikāta sapropelis ir mazāk bagāts ar organiskām vielām (25-60\%), bet tam ir liels kopējais mikroelementu saturs.

Pēc saguluma īpatnībām sapropel̦a iegulas iedala atklātās un apbēruma. Atklātie nogulumi nogulsnējas mūsdienu ūdenstilpēs un to uzkrāšanās turpinās arī mūsdienās. Apbēruma sapropelis nogulsnējas parasti zem kūdras slāņa, reti zem minerālajiem sanešiem, tādējādi tā sedimentoǵenēzes stadija ir beigusies [19].

20. gs. 70 gados baltkrievu zinātnieki M. Zolopotko un G. Jevdokimova izstrādāja sapropel̦a klasifikāciju (sk. 3. tabulu), izvērtējot rūpniecības prasības un sapropeļa ǵenēzes principus [20]. Šì klasifikācija ir balstīta uz nogulumu ķīmiskās struktūras septinu rādītāju kvantitatīivo analīzi - katrs izdalītais sapropel̦a tips tiek noteikts pēc izmantošanas principa. Šì ir vissarežğîtākā sapropeļa klasifikācija.

Pēc organiskās un minerālās daḷas attiecības autori iedala sapropeli mazpelnainā (pelnainība mazāka par 30\%) un augsti pelnainā (pelnainība no 31-85\%) sapropelī. Mazpelnainais sapropelis tiek iedalīts 4 veidos pēc humusvielu un viegli hidrolizējamo vielu proporcijas - princips sasaistāms ar olbaltumvielu ǵenēzi. Oр $\Gamma_{1}$ veida nogulumi (skat. 3. tabulu) satur lielu daudzumu alohtonā (svešas izcelsmes) humusvielu materiāla. Pie pārējiem trim organiskā sapropel̦a veidiem pieskaita sapropeli, kura humusvielas veidojas no autohtona (vietējās izcelsmes) materiāla.

Humusa materiāla pārnese no ūdenstilpes nodrošina lielāku humusvielu daudzumu, kuras satur mazāk ūdeņraža un slāpekḷa $\left(\mathrm{Op}_{4}\right.$ veids). Caurteces ezeros intensīvas oksidācijas 
un sadalī̌sanās procesu rezultātā nestabili savienojumi uzkrājas stabilāku humīnskābju veidā ar aromātisku struktūru fragmentiem $\left(\mathrm{Op}_{2}\right.$ veids). Vidējais humusvielu daudzums ir raksturīgs sapropelim, kas veidojas pie augstas produktivitātes organisko vielu klātbūtnē (Op $\Gamma_{3}$ veids). Intensīvas nogulu uzkrāšanās gadījumā notiek ātra aerobo apstākḷu nomaina uz anaerobiem, kas sekmē intensīvu humīnskābju veidošanos $\left(\mathrm{Op} \Gamma_{1}\right.$ veids). Augsti pelnainā sapropel̦a grupa, balstoties uz minerālās daļas ķīmisko analīzi, iedalās 3 veidos: silīcija dioksīdu saturošais, karbonātu un jauktais sapropelis. N̦emot vērā sapropel̦a sastāvu un īpašības, š̄ klasifikācija atbilst racionālākajam sapropel̦a izmantošanas principam.

3. TABULA

SAPROPEL̨A RŪPNIECISKI ĢENĒTISKĀ KLASIFIKĀCIJA [20]

\begin{tabular}{|c|c|c|c|c|c|c|}
\hline \multirow{2}{*}{$\stackrel{n}{=}$} & \multirow[b]{2}{*}{ Veids } & \multirow[b]{2}{*}{ Apzīm. } & \multicolumn{2}{|r|}{ Veida diagnostikas pazīmes } & \multirow[b]{2}{*}{ Izmantošana } & \multirow{2}{*}{$\begin{array}{l}\text { Diagnostikas } \\
\text { rādītāji }\end{array}$} \\
\hline & & & $\mathbf{A}_{\mathbf{c}}, \%$ & $\begin{array}{c}\text { Bioloğiskais sastāvs un } A_{c} \\
\text { oksīdi, \% }\end{array}$ & & \\
\hline \multirow{4}{*}{ 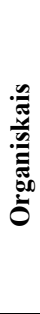 } & Kūdrainais & $\mathrm{Op}_{1}$ & $<30$ & kūdras veidotājaugi $>70$ & $\begin{array}{l}\text { Augšanas stimulatori, HV preparāti, mēslojums, } \\
\text { celtniecības materiālu ražošana }\end{array}$ & \multirow{4}{*}{$A_{c}$ (pelnainība) } \\
\hline & Organisks ar augstu HV saturu & $\mathrm{Op}_{2}$ & $<30$ & $\begin{array}{r}\text { kūdras veidotājaugi un } \\
\text { üdensaugi }\end{array}$ & $\begin{array}{l}\text { Ārstnieciskās dūṇas, biologíski aktīvas vielas, } \\
\text { mēslojums }\end{array}$ & \\
\hline & Organisks ar vidēju HV saturu & $\mathrm{Op}_{3}$ & $<30$ & kramaļ̣ges un zilaḷ̆ges - & $\begin{array}{l}\text { Pildvielas, urbšanas šḳīumu, ārstnieciskās dūṇas, } \\
\text { mēslojums }\end{array}$ & \\
\hline & Organisks ar zemu HV saturu & $\mathrm{Op}_{4}$ & $<30$ & zal̦aļges - & $\begin{array}{l}\text { Saistviela, urbšanas šķīdumi, ārstnieciskās dūņas, } \\
\text { mēslojums }\end{array}$ & \\
\hline \multirow{4}{*}{ 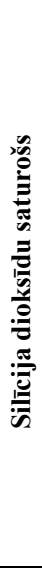 } & Silikāta ar zemu pelnu saturu & $\mathrm{Kp}_{1}$ & $30-50$ & $\begin{aligned} \text { diatomejas } & >90 \\
\mathrm{SiO}_{2} / \mathrm{CaO} & >2 \\
\mathrm{Fe}_{2} \mathrm{O}_{3} & <10\end{aligned}$ & $\begin{array}{l}\text { Mēslojums, urbšanas šķīidumi, celtniecības } \\
\text { materiālu ražošana, ārstnieciskās dūņas }\end{array}$ & \multirow{4}{*}{$\begin{array}{l}\mathrm{A}_{\mathrm{c}} \\
\mathrm{SiO}_{2} / \mathrm{CaO} \\
\mathrm{Fe}_{2} \mathrm{O}_{3}\end{array}$} \\
\hline & Silikāta ar augstu pelnu saturu & $\mathrm{Kp}_{2}$ & $50-85$ & $\begin{aligned} \text { diatomejas } & >90 \\
\mathrm{SiO}_{2} / \mathrm{CaO} & >10 \\
\mathrm{Fe}_{2} \mathrm{O}_{3} & <10\end{aligned}$ & $\begin{array}{l}\text { Augšnu kolmatācija, tamponāžžas šksīidumi, } \\
\text { mēslojums }\end{array}$ & \\
\hline & Autogēni silikātu & $\mathrm{Kp}_{3}$ & $30-50$ & $\begin{aligned} \text { diatomejas } & >90 \\
\mathrm{SiO}_{2} / \mathrm{CaO} & >2 \\
\mathrm{Fe}_{2} \mathrm{O}_{3} & <10\end{aligned}$ & Augšanas stimulatori, ārstnieciskās dūņas & \\
\hline & Silikātu dzelzs & $\mathrm{Kp}_{4}$ & $>30$ & $\begin{aligned} \text { diatomejas } & >90 \\
\mathrm{SiO}_{2} / \mathrm{CaO} & >2 \\
\mathrm{Fe}_{2} \mathrm{O}_{3} & >10\end{aligned}$ & Ārstnieciskās dūṇas & \\
\hline \multirow{2}{*}{ تَّ人 } & Karbonātu & Карб $\sigma_{1}$ & $>30$ & $\begin{array}{c}\mathrm{SiO}_{2} / \mathrm{CaO}<0,4 \\
\mathrm{Fe}_{2} \mathrm{O}_{3}<5\end{array}$ & $\begin{array}{l}\text { Ar minerāliem un vitamīniem bagātas dzīvnieku } \\
\text { barības piedevas, ārstnieciskās dūņas, augsnes } \\
\text { kal̦ķošana }\end{array}$ & \multirow{2}{*}{$\begin{array}{l}\mathrm{A}_{\mathrm{c}} \\
\mathrm{SiO}_{2} / \mathrm{CaO} \mathrm{Fe} \mathrm{O}_{3} \\
\text { Minerālvielas = } \\
=\mathrm{A}_{\mathrm{c}}+\mathrm{CO}_{2}\end{array}$} \\
\hline & Karbonātu dzelzs & Карб $\sigma_{2}$ & $>30$ & $\begin{array}{c}\mathrm{SiO}_{2} / \mathrm{CaO} 0,4-0,7 \\
\mathrm{Fe}_{2} \mathrm{O}_{3}>5\end{array}$ & $\begin{array}{l}\text { Augšņu kalķošǎana, tamponāžas šķīdumi, } \\
\text { ārstnieciskās dūņas }\end{array}$ & \\
\hline \multirow{4}{*}{ 竎 } & $\begin{array}{l}\text { Jauktais organiski silikāta } \\
\text { karbonātu }\end{array}$ & $\mathrm{CM}_{1}$ & $>30$ & $\begin{aligned} & \mathrm{SiO}_{2} / \mathrm{CaO} 0,7-2,0 \\
& \mathrm{SiO}_{2} / \mathrm{Fe}_{2} \mathrm{O}_{3}>4 \\
& \mathrm{CaO} / \mathrm{Fe}_{2} \mathrm{O}_{3}>3 \\
& \mathrm{SO}_{3}>10\end{aligned}$ & $\begin{array}{l}\text { Mēslojums, celtniecības materiālu ražošana, } \\
\text { ārstnieciskās dūṇas }\end{array}$ & \multirow{4}{*}{$\mid \begin{array}{l}\mathrm{A}_{\mathrm{c}} \\
\mathrm{SiO}_{2} / \mathrm{CaO} \\
\mathrm{SiO}_{2} / \mathrm{Fe}_{2} \mathrm{O}_{3} \\
\mathrm{CaO} / \mathrm{Fe}_{2} \mathrm{O}_{3} \mathrm{SO}_{3}\end{array}$} \\
\hline & $\begin{array}{l}\text { Jauktais silikātu karbonātu, } \\
\text { dzelzs }\end{array}$ & $\mathrm{CM}_{2}$ & $>30$ & 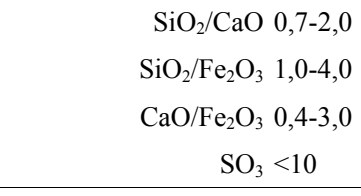 & $\begin{array}{l}\text { Urbšanas šk̄īumi, celtniecības materiālu ražošana, } \\
\text { ārstnieciskās dūņas }\end{array}$ & \\
\hline & $\begin{array}{l}\text { Jauktais organiski silikātu, } \\
\text { dzelzs }\end{array}$ & $\mathrm{CM}_{3}$ & $>30$ & $\begin{array}{rl}\mathrm{SiO}_{2} / \mathrm{CaO} & 0,7-2,0 \\
\mathrm{SiO}_{2} / \mathrm{Fe}_{2} \mathrm{O}_{3} & <1 \\
\mathrm{CaO} / \mathrm{Fe}_{2} \mathrm{O}_{3} & <0,4 \\
\mathrm{SO}_{3} & <10\end{array}$ & Ārstnieciskās dūņas & \\
\hline & $\begin{array}{l}\text { Jauktais organiski karbonātu, } \\
\text { sulfâtu }\end{array}$ & $\mathrm{CM}_{4}$ & $>30$ & $\begin{aligned} & \mathrm{SiO}_{2} / \mathrm{CaO} 0,7-2,0 \\
& \mathrm{SiO}_{2} / \mathrm{Fe}_{2} \mathrm{O}_{3}>1 \\
& \mathrm{SO}_{3}>10\end{aligned}$ & Ārstnieciskās dūņas & \\
\hline
\end{tabular}


Latvijā ievērojamākie sapropel̦a pētījumi saistās ar N. Brakšu, kas par svarīgāko k̦īmiski tehnoloǵisko sapropel̦a nogulumu īpašību uzskatîja pelnainību - sapropel̦a mineralizācijas pakāpi (sausās masas pelnainība $A_{c}, \%$ ), kas nosaka iespēju nogulumus praktiskai izmantošanai. Viņš iedala sapropeli 3 grupās pēc organiskās un minerālās daḷas attiecības: mazpelnaini $\left(\mathrm{A}_{\mathrm{c}} \operatorname{li} \mathrm{dz} 30-35 \%\right)$, vidēji pelnaini $\left(A_{c} 35-50 \%\right)$ un nogulumi ar augstu mineralizācijas pakāpi $\left(\mathrm{A}_{\mathrm{c}}\right.$ vairāk par 50\%) [4].

Sapropel̦a ķīmisko īpašību un termiskās pārstrādes iespējas izvērtēšanai N. Brakšs izmantoja koksēšanas analīzi, nosakot darvas un koksa procentuālo daudzumu, attiecinot to pret sapropel̦a organisko masu, sasaistot šīs īpašības ar sapropeḷa mineralizācijas pakāpes grupām.

\section{SAPROPEL̦A VEIDOŠANĀS}

Daudzi krievu zinātnieki uzskata, ka sapropelis ir savdabīgs geologisks veidojums, kas rodas ūdenstilpes pamatnē visā tās pastāvēšanas laikā [15], [19], [21]. M. Leinerte uzskata, ka sapropel̦a veidošanās ir l̦oti atkarīga no sapropel̦a iegulas ezera - tipa, kas nosaka tā rašanos un attīstîbu, un apgalvo, ka sapropeḷa nogulumu veidošanās var norisināties tikai vielu un enerğijas pastiprinātas uzkrāšanās zonās, šs̄ parādība plaši novērojama eitrofajos ezeros [1].

Mūsdienu sapropel̦a atradnes - purvi un ezeri - ledāja nogulumu rajonos varēja rasties tikai pēc ledāja atkāpšanās. Baltijas valstīs tas notika pirms 12 - 15 tūkstošiem gadu [22]. Kopš izcelšanās līdz mūsdienām ezeri nepārtraukti mainās un attīstās, tas lielā mērā ir atkarīgs no klimatiskajiem apstākḷiem. Masveida sapropel̦a veidošanās notika holocēnā (10 000 g.p.m.ē. - mūsdienas), tā senāko nogulumu vecums ir 11 - 12 tūkstoši gadu, un, tas ir ne tikai vērtīgs dabas resurss, kuru var izmantot daudzās tautsaimniecības jomās, bet arī uzskatāms materiāls pagātnes klimata izmainu pētī̌sanai [22] - [25].

Ja klimata izmaiņas ietekmē galvenokārt ezera ūdens līmeni - sausajos periodos ūdens līmenis krītas, bet mitrajos paaugstinās, tad nepārtraukta nogulumu uzkrāšanās ezerdobē ir nozīmīgākais faktors ezera attīstības gaitā. F. Forels [26] iedalīja ezerus vecuma periodos pēc to ezerdobes attīstības pakāpes: jaunība, briedums, vecums, vecuma panīkums un atmiršana. Katram vecumam atbilst noteikts ezera tips, bet galu galā jebkurš ezers eitroficējoties kḷūst distrofs, un, aizaugot vai pāraugot atmiršanas periodā, pārtop par purvu, tāpēc Latvijā 2/3 no sapropeḷa krājumiem atrodas tagadējos purvos zem kūdras slāna.

Pašlaik vidējais nogulumu uzkrāšanas slānis gadā svārstās no $0,1 \mathrm{~mm}$ mazos, beznoteces ezeros $1 \overline{1} \mathrm{dz} 4,3 \mathrm{~mm}$ lielos, caurteces ezeros, daudzgadējais vidējais rādītājs: nelielos ezeros bez noteces ir $1,05 \mathrm{~mm}$, nelielos ezeros ar caurteci $3,56 \mathrm{~mm}$ un lielos ezeros ar labu caurteci - 6,64 mm [27].

Sapropelim var būt gan autohtona izcelsme, ja tā uzkrāšanās notiek ezera biomasas uzkrāšanās rezultātā, gan alohtona izcelsme, gadījumos, kad nogulumos uzkrājas liels humusvielu daudzums, kas nonāk ezerā no apkārtējām teritorijām un purviem [28] - [30]. Par vērtīgāku tiek uzskatîts autohtonas izcelsmes sapropelis ar augstāku organisko vielu saturu, jo sākotnējā biomasa un tās bioḳīmiskā sadalīšanās, kā arī pārvēršanās sapropel̦a organiskajās vielās ūdenstilpes apstākl̦os neveicina policiklisko aromātisko ogl̦ūdeņražu, piemēram, benzopirēna veidošanos, kas ir raksturīgs augsnes, kūdras un sevišksi og̣̦u humusvielām [31].

Šodien pastāv vairāki viedokḷi par sapropeḷa veidošanos. G. Potenje izvirzīja teoriju, ka sapropel̦a veidošanās ir mehāniska planktona sadalīšanās atlieku - vasku un tauku uzkrāšanās ūdens baseinos [32], ignorējot ogl̦ūdeņražu, augstāko augu olbaltumvielu un jaunu savienojumu sintēzes lomu [31], [33].

E. Kazakovs vēlāk kritizēja G. Potenje teoriju apgalvojot, ka jāṇem vērā arī citi sapropeḷa veidotāji - augstākie ūdensaugi, floras un faunas bentiskās formas - to sadalī̌sanās un sintētiskie procesi, piemēram, humusvielu tipa savienojumu rašanās no og̣̦idrātu un olbaltumvielu skaldproduktiem (sk. 1.attēls).

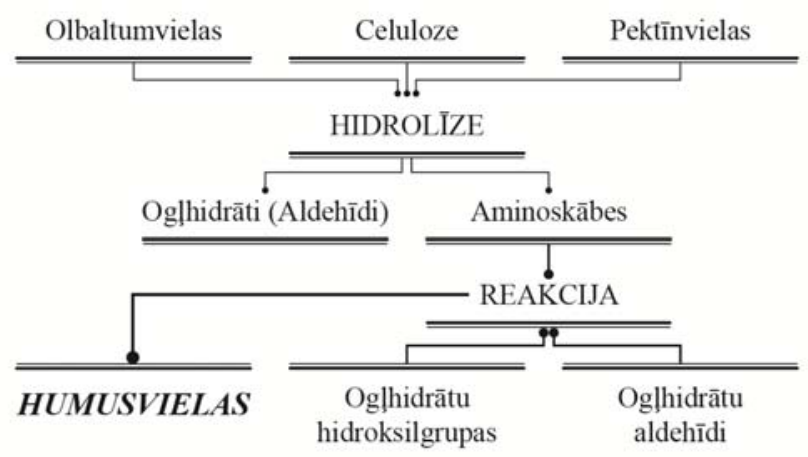

1. att. Sapropel̦a organisko vielu iedalījuma shēma [34].

Vairāki zinātnieki uzskata, ka sapropelis veidojas vienkāršiem augiem un dzīvniekiem lielos daudzumos ātri savairojoties un uzkrājoties ezeros. Atmirstot tie nogulsnējas nogulšnu veidā ezera dibenā. Piemēram, vasarā ūdenstilpēs attīstās dažādas fitoplanktona sugas, zilaḷǵes, zaļalı́ges, kramalğges u.c., bet atmirstot šo organismu atliekas, kas bagātas ar taukiem, olbaltumvielām, fosforu, kāliju, kalciju un celulozi, kḷūst par sapropel̦a komponentiem. Humusvielas, kalcija un dzelzs sāḷi ūden̄i paātrina koagulācijas un nogulsnēšanās procesus [30], [35], [36].

Sapropeḷa pamatsastāvu veido trīs komponenti: alohtonas izcelsmes minerālvielas, biogēnas izcelsmes neorganiskie komponenti, ezerā un tā apkārtnē mītošo augu un dzīvnieku atliekas - organiskās vielas.

Ezera hidroloǵiskais režīms, noteces baseina īpašības un lielums ir nozīmīgi faktori ezera nogulumu veidošanā. Alohtonais minerālais materiāls nonāk ezerā no sateces baseina teritorijas un ezerā ietekošām upēm. Lielā koncentrācijā tas ir sastopams upju deltās un ezeros vērsto stāvu nogāžu tuvumā [37], [38]. Parasti augsta minerālvielu koncentrācija ir novērojama ezera sākumstadijas attīstībā, bet ezeram aizaugot un kḷūstot seklākam, krastiem lēzenākiem, šo vielu ienese samazinās. Ezerā no apkārtējām teritorijām ietekošie ūden̦i var saturēt daudz minerālo vielu, tādā veidā stipri ietekmējot ezera nogulumu, kas nogulsnējas ezera stāvošo ūdeṇu dal̦ā, minerālo sastāvu. Jo mazāks ir ezers, jo vairāk to ietekmē pietekas ūdeni un minerālo dalinu ienese no krastiem. Sateces baseina lielums un tā virsmas erozija nosaka virsējās noteces duļ̧̦ainumu. 
Karbonāti, kuriem ir autohtona izcelsme [30], veidojas bikarbonātu $\left(\mathrm{HCO}^{-3}\right)$ pārsātinātos ūdeños. Zooplanktona, fitoplanktona un bentosa intensīvas attīstības laikā ūdenī rodas $\mathrm{CO}^{2-}$ pārsātinājums, kas ir pamats karbonātu kristālu veidošanai [39], [40].

Sapropel̦a organiskās vielas parasti ir autohtonas izcelsmes, tās veido aļgu un zooplanktona atliekas, bet lapas, putekšņi un augu sporas tiek ienestas ūdenstilpē no apkārtējām teritorijām [41].

Sapropel̦a sarežğīto ķīmisko struktūru nosaka tā veidotājorganismu bioķīmiskā daudzveidība. Sapropel̦veidotāju organismu - hidrobiontu daudzveidība ūdens ekosistēmās pēc nozīmes un veidošanās iedalās 2 lielās grupās: 1) primārie producenti (augi un daļa mikroorganismu) - piedalās jauno organisko vielu veidošanā un kustīgo minerālo vielu akumulācijā; 2) sekundārie producenti (baktērijas, sēnes, dz̄̄vnieki) - veido organiskās vielas no primāro producentu veidotām organiskām vielām vai to sadales produktiem, to biomasa ir 2-3 reizes mazāka nekā primāro producentu organisko vielu biomasa [42].

Sekundārie producenti, kas masveidā attīstās ūdenstilpēs, ir zooplanktons (vēžveidīgie, kukaiṇu kāpuri) un bentoss (vēžveidīgie, kukaiṇu kāpuri, moluski u.c.) [43]. Dažādos sapropeḷa tipos atrastās hitīna un kalıķakmens skeletu paliekas sastāda $1-25 \%$. Dz̄̄vnieku atlieku diagnostika nogulumu vertikālajā stratifikācijā l̦auj rekonstruēt ǵeologiski klimatiskos apstākḷos sapropel̦a nogulumu veidošanās laikā [7], [27].

Zooplanktona un bentosa bioķīmiskie parametri ir nepastāvīgi un lielā mērā atkarīgi no organismu dzīves apstākḷiem un fiziologískā stāvokḷa [44], [45].

Ūdens ekosistēmu primārie producenti, kas veido jaunas organiskās vielas un akumulē mobilas minerālās vielas, ir mikrofìti - mikroskopiski ūdensaugi, planktons un bentoss, un makrofìti - augstākie ziedaugi un mietturaļges. Saldūdens mikroskopiskās alıǵes iedalās četrās galvenajās klasēs: zaḷaḷges (Chlorophyta), kramaļǵes (Diatoma), dzeltenzal̦ās aļges (Xanthophyta) un zilalıges (Cyanophyceae) [7].

Augstākie ūdens augi arī tiek uzskatîti par nozīmīgiem sapropel̦a veidotājiem, tos iedala: sūnaugi, kosas, glīvenes, mazlēpes, graudzāles, grīş̧i u.c. Paaugstināts ezera makrofìtu un kūdras veidotājaugu īpatsvars ir raksturīgs distrofo ūdenstilpju un purvu sapropelim. Šiem nogulumiem arī ir raksturīga augsta putekšņu un sporu koncentrācija (līdz 19\%). Augstāko augu atlieku daudzums mainās robežās $1-80 \%$ no kopējās biomasas.

Daži zinātnieki uzskata, ka svarīgākie ezera sapropeļa veidotāji ir aļges [20], [35] - tām ir liela nozīme daudzu iežu veidošanā Zemes geologiskajā vēsturē. Zemākie vienšūṇi un koloniālās aḷges veido degslānekḷus - kukersits, balhašìts, nhangelīts, kurongīts u.c.

Ezera nogulu veidošanā liela nozīme ir autohtonas izcelsmes organiskajām vielām, jo tās ir daudzu barības k̦ēěu pamats un nosaka ezera produktivitāti - Saules enerǵijas summu, ko autotrofie augi un fitoplanktons fotosintēzes procesā pārvērš par organiskajām vielām. Producenti ir vienīgie organisko vielu ražotāji, kas veido barības vielu krājumus pārējiem barības k̦ēdes pārstāvjiem. Citās barības cikla stadijās, izmantojot skābekli un izkliedējot enerǵiju, notiek šo organisko vielu sadalīšana [46], [47].
Katras barības cikla stadijas beigu posmā rodas ezera nogulumu slāni papildinošs materiāls, taču to ierobežo organisko vielu mineralizācija, kas notiek aerobo mikroorganismu ietekmē. Mijiedarbība starp organisko vielu produkciju un destrukciju ir viens no galvenajiem faktoriem, kas nosaka ezera nogulumu īpašības un veidu [27].

Pie sapropel̦a nogulumu veidošanās piedalās trīs ezeru vielu grupas: izšķ̄īušas organiskās vielas, detrīts un mikroorganismi.

Pēc K. Judaja aprēķiniem augu kopējā masa ezeros ir 6 20 reizes lielāka nekā tajā dzīvojošo dzīvnieku masa. Izšksīdušo organisko vielu daudzums vienmēr ir lielāks nekā kopējais organiskā materiāla - dzīvo dzīvnieku, augu un detrīta svars, jo visi dzìvie organismi izdala un izvada izdalījumus un ekskrementus, tie visi iet bojā, to atliekas sadalās, tādā veidā papildinot ūden̄̄ izšķ̄īdušās organiskās vielas [48]. Šo vielu sastāvā ietilpst slāpekli saturošie savienojumi (olbaltumvielas, peptīdi, aminoskābes), ogḷūdeņraži, lipīdi, organiskās skābes, vitamīni, hormoni vielas, kuras asimilē heterotrofi hidrobionti (dz̄ivie organismi, kuri sev nepieciešamo organisko savienojumu sintēzei kā oglekḷa avotu izmanto citu organismu sintezētas, reducētas oglekḷa atomus saturošas organiskas vielas). Eitrofos ezeros izšķīdušo organisko vielu $77-83 \%$ masas veido humusvielas, kas sastāv no grūti sadalāmiem komponentiem - humīna, humīnskābēm un fulvoskābēm [30], [49].

Detrīts ir suspendētas, lēni grimstošas, bagātas ar tauku, olbaltumvielu un vasku daļiņas, kuru sastāvā ietilpst organiskas (organismu sabrukšanas produkti un sorbētu organisko vielu produkti), minerālās vielas (sanesu un krastu izskalošanas komponenti), ūden̄̄ brīvi peldošas baktērijas, sēnes un vīrusi [37]. Detrīts satur gan organiskas, gan arī neorganiskas daļinas, tajā norisinās koloīdu sorbcija un koagulācija. Detrīta organiskā daļa ir sorbētas organiskās vielas un dzīvās baktērijas [50]. Tās avots ir fitoplanktons, kurš sastāv no 55 - $61 \%$ olbaltumvielām un $1,2-4,0 \%$ taukiem. Zooplanktons un bentoss sastāv no $56-61 \%$ olbaltumvielām un līdz 26\% ūdenī šksīstošām vielām. Tauku, vasku un sveķu saturs planktonā un bentosā ir samērā neliels [51].

Mazās ūdenstilpēs organiskās vielas pēc to sadalī̌sanās nogrimst ezera dibenā un tiek intensīvi mikrobiolog̣iski pārstrādātas. Ezera attīstības beigu stadijā, tam aizaugot, par organisko vielu avotu detrītam kḷūst augi - makrofīti, kas veido rupju detrītu un piešķir sapropelim tumšu krāsu. Detrīts, kas veidojās no zemāko augu un dzīvnieku atliekām un to ekskrementiem, veido koloidālu, mīkstu, taukainu masu, kas var būt dažādās krāsās [19]. Nogulumu augšējos slāņos, palielinoties sapropeḷa transformācijas pakāpei, uzkrājas humusvielas, kas ir tumši brūnā vai melnā krāsā, tās nosaka nogulumu krāsu no tumši olīvzaļas līdz tumši brūnai [45].

Detrītā ietilpstošās minerālvielas pēc izcelsmes var būt autohtonas - silīcija un kaļķa nogulumi, kas ir veidojušies ezeros ķīmisko procesu rezultātā, tās var arī būt alohtonas ienestas no apkārtējās teritorijas.

Mikroorganismiem sapropeḷa veidošanās gaitā arī ir nozīmīga loma. Tie ir universāli reducenti, kuri savu dz̄ivības procesu uzturēšanai parasti izmanto organiskās vielas. To vidū ir arī baktērijas, kuras kā enerǵijas avotu izmanto ar̄̄ 
neorganiskas vielas: sērūdenradi, amonjaka savienojumus, fosforu un kāliju [31].

Mikroorganismi paātrina vai palēnina metaboliskos procesus - tiem ir svarīga loma ezera nogulumu veidošanā. Mikroorganismu darbību ietekmē skābeklis. Ezera nogulumos norisinās bioloǵisku un ķīmiski fizikālu procesu kopums, kurā savā starpā mijiedarbojas oksidētāji un reducētāji, tas savukārt rada piemērotu vidi citu mikroorganismu pastāvēšanai [18], [52].

Pēc skābekḷa daudzuma ezerā tas var tikt iedalīts trīs zonās - krasta, dziḷūdens un bezskābekḷa (anoksiskā zona). Mikroorganismiem iedarbojoties uz ezera dūṇām, tajās izbeidzas nogulumu daļinu mehāniska kustība un tās pāriet miera stāvoklī. Krasta zona ir bagātāka ar skābekli, ko rada fitoplanktons un ūdens virsmas spēja saistīt skābekli no gaisa. Sadalīšanās procesi šajā zonā norit intensīvāk. Dziḷūens slāņos skābekḷa koncentrācija ir zema, sadalīšanās procesi lēnāki, organiskajām vielām pārklājoties ar jauniem nogulumu slāņiem, izveidojas anaeroba vide un mikroorganismu darbība apstājas [18], [37], [52]. Bezskābekḷa zonā aerobo sadalīšanās procesu nomaina anaerobais - oksidēšanās notiek, reducējoties skābekli saturošiem savienojumiem. B. Perfiljevs uzskata, ka sapropel̦a veidošanās mehānisms ir balstīts uz divām difūzām ūdens plūsmām nogulumos. Šīs plūsmas veidojas savā starpā saskaroties ūdenim, kas fotosintēzes rezultātā ir piesātināts ar izšksīidušo skābekli, un ūdenim, kas anaerobu procesu rezultātā ir nabadzīgs ar izšksīdušo skābekli. Šo plūsmu difūzija samazinās virsējos slāņos - pelogēnā, parādoties ūdenī mazšķīstošām gāzēm, kuras uzpeldot rada burbulīšus. Skābekḷa nokḷūšanu sedimentos virzienā no augšas uz leju sekmē tārpu un kūniņu vertikālās ejas. Dziḷākos sapropeḷa slāņos ir anaeroba vide; sapropelis kḷūst par bioloǵiski inertu vielu, no bioloǵiskas sfēras pāriet ǵeoloǵiskā, kur zemas temperatūras termolīzē lielākā daļa organisko vielu pakāpeniski kḷūst nešķīstošas [52].

Ezera nogulumu veidošanās teorija izskaidro nogulumu pamata slāṇa sīkslaṇainās struktūras veidošanos un var kalpot par ūdenstilpes un tās apkārtnes vēsturisko hroniku. Š̄is teorijas pamatā ir doma, ka nogulumu slāņi ir gada slāņi, pēc kuru daudzuma var spriest par ūdenstilpes dzīves ilgumu [18], [52].

Dziļos oligatrofajos ezeros, kur organisko vielu saturs ir zems, izgulsnējas galvenokārt minerālie nogulumi.

Nedziḷās ūdenstilpēs (2 - 20 m dziḷas), kurām ir neliela platība un zema caurtece, veidojas labvēlīgi apstākḷi organisko vielu nogulsnēšanās procesam ezerā. Šo ezeru ūdeņi satur pietiekamu daudzumu barības vielu, kuras, nogulumos noritošo ķīmisku un bioķīmisku procesu rezultātā, pārveidojas, izmainot piegrunts ūdens slāņa sastāvu. Nogulumi izdala gāzes: metānu 75 - 95\%, ūdeņradi - 5 - 15\% un $\mathrm{CO}_{2}$ līdz 3\%, kuru daḷa izšksīst ūden̄̄ un nenonāk līdz ūdens virsmai. Šīs gāzes izdala $1 \mathrm{~m}$ biezs nogulumu virsējais slānis, turklāt to izdalīšana ir raksturīga sekliem, labi sasildītiem ezeriem eitrofajiem un distrofajiem - bagātiem ar organisko vielu slāņiem.

Sapropel̦a nogulumu uzkrāšanās aizsākas ezera padziļinājumos, ap $1-2 \mathrm{~mm} /$ gadā. Šos nogulumus sāk aktīvi ietekmēt pelogēna slāṇa (nogulumu veidošanas slāṇa) organismi, kas dzīvo ezera dibenā un baktērijas, kas dzīvo ezera nogulumu virsējos slāņos. Tie sasmalcina, sablīvē un dal̦ēji pārveido nogulumus, bet pēc nāves papildina nogulumu sastāvu ar savām atliekām [53]. Intensīvāki bioloǵiski procesi notiek $20-60 \mathrm{~cm}$ biezā nogulumu virsējā slānī, kur baktēriju skaits 1 nogulumu gramā sastāda $8-60$ miljardus un to summārā masa ir $2-8 \%$ no nogulumu organisko vielu masas [31].

Nogulumu biezums, īpašības un sastāvs lielā mērā ir atkarīgs no reǵiona ǵeogrāfiskiem apstākḷiem un cilvēka darbības ietekmes.

\section{SAPROPEL̨A SASTĀVS}

Sapropeli veido trīs galvenās sastāvdaḷas jeb komponenti, kas savā starpā mijiedarbojas - organiskā un minerālā daḷa un sapropel̦a sastāvā ietilpstošie dzīvie organismi.

\section{A. Sapropela organiskās vielas}

Sapropel̦a organiskās vielas var tikt definētas dažādi:

- hidrobiontu neizšķ̄īdušās atliekas un koloidālās autohtonās vielas, kas tiek ienestas terigēnajā notecē. Tā ir biologisku un organisku komponentu summa [42], [54];

- mazmolekulāru organisko savienojumu, biopolimēru un adsorbcijas kompleksi ar minerāliem [45].

Sapropel̦a organisko vielu definējums ir atkarīgs no pētījumu virziena, piemēram, ķīmiski analizējot sapropeli, vairākums zinātnieku izmanto Lopotko definīciju, neņemot vērā organisko molekulu atbrīvošanos un pāreju uz molekulāro organizācijas līmeni, sadaloties organismiem [55].

N. Kurmuševa [56], klasificējot organisko vielu biolìtus iežus, kas pārsvarā sastāv no izmirušu dzīvnieku, augu un to dzīves produktu paliekām, noteica sapropeli kā humusvielu zemūdens formu, bet citi zinātnieki [57] izšksir augsnes, kūdras un sapropel̦a humusvielas, uzskatot tos par dažādas izcelsmes organisko vielu uzkrāšanās formām.

Nikolajeva un Bakšienes definējums [42], [54] nosaka, ka sapropel̦a organiskās vielas veido ūden̄̄ dzīvojošie organismi - aḷǵes, fitoplanktons, zooplanktons, augstākie ūdens dzīvnieki un augi. Šo veidotājorganismu atliekas nosaka sapropel̦a īpašības un izmantošanas iespējas. Piemēram, zaļaļgu apvalki sastāv pārsvarā no celulozes [37], kas slikti sadalās laika gaitā, līdz ar to sapropelis, kura organiskās masas īpatsvaru veido zaļaļges, ir bagāts ar celulozi, bet nabadzīgs ar humusvielām un minerālvielām. Tas nozīmē, ka šādu sapropeli ir racionāli izmantot kā līmvielu dažādu ekoloǵisku būvniecības materiālu ražošanā.

Lopotko sapropel̦a organisko vielu definējums var tikt pielietots, apskatot sapropel̦a ķīmisko sastāvu un īpašības, kas ir sapropel̦a organiskās masas elementsastāvs: oglekḷa (C), ūdeņraža (H), skābekḷa (O), slāpekḷa (N) un sēra (S) saturs. Šo elementu vidējais sastāvs sapropel̦a organiskajās vielās ir (normalizēts \%): C 60,0; H 6,0; N 2,5; O 35,0 [58].

N. Brakša pētījumos elementu saturs (\%) dažādu atradņu sapropelī ir mainīgs $\mathrm{C}=51-59 ; \mathrm{H}=6,5-7,4$; $\mathrm{C} / \mathrm{H}$ attiecība $\approx 7,0-8,9$ [22].

G. Jevdokimova, pētot sapropeli 130 atradnēs Baltkrievijā, noskaidroja, ka C, H un N svārstības vienā sapropel̦a tipā ir atkarīgas no to veidojošiem komponentiem. Paaugstināts $\mathrm{C}$, 
bet pazemināts $\mathrm{H}$ un $\mathrm{N}$ saturs ir raksturīgs nogulumiem, kuri satur $40-60 \%$ humusvielu un kuri veidojas galvenokārt no kūdru veidojošiem augiem. Sapropelī ar lielāku zoogēno atlieku daudzumu $\mathrm{H}$ un $\mathrm{N}$ saturs pieaug, bet $\mathrm{C}$ - samazinās [20].

Latviešu zinātnieki pierādīja, ka slāpekḷa (N) saturam ar sapropel̦a mineralizācijas pakāpi nav tiešu sakarību, jo sapropelim ar atšķirīgu pelnainību ir aptuveni vienāds slāpekḷa daudzums, bet slāpekḷa sadalījuma sastāvam nogulumu vertikālos griezumos dažādās atradnēs (arī pelnainībai) ir dažāds raksturs[4], [22].

M. Lopotko uzskata, ka slāpekḷa maksimālās koncentrācijas atrodas pelogēnā $(7,0$ - 7,5\% no organiskām vielām) - slānī, kurā aktīvi norit mikrobioloǵiski un bioḳīmiski procesi, uzkrājas liels daudzums mikroorganismu olbaltumvielu un zilậgu no gaisa fiksētā slāpekḷa [36].

Slāpekḷa izmaiņas nogulumu vertikālajos griezumos, tāpat kā citus ķ̄imiskos rādītājus, var izmantot sapropeḷa slāņa sadalīšanai atsevišķos stratigrāfiskajos horizontos.

Slāpekḷa vidējais saturs Latvijas ezeru sapropeḷa paraugos mainās no 1,2 - 4,7\% [22], arī E. Kazakova saldūdens sapropel̦a organisko vielu pētījumos tika noteikts slāpekḷa saturs līdz $4-5 \%$ [34].

Dažāda tipa sapropel̦a nogulumos slāpekḷa saturs mainās no 2,7 līdz $6 \%$ organiskajās vielās vai $0,5-4,0 \%$ no sausas masas. Sapropelis ar augstu dzīvnieku atlieku daudzumu satur vairāk slāpekḷa $(4,4-4,8 \%)$ nekā aļgu $(3,0$ - 4,2\%) vai kūdras sapropelis $(2,6-3,5 \%)$ [55].

Sēra saturs sapropeḷa organiskajās vielās mainās no 0,1 līdz $1,8 \%$, nepārsniedzot $3 \%$ sausajā masā, taču, rūpnieciski sagatavojot un glabājot sapropeli, sēra savienojumi oksidējas, kas paaugstina tā apmaiņas skābumu [20], [44], [45]. Augstākas sēra koncentrācijas organiskajās vielās ir sastopamas karbonāta sapropelī [12], [59].

Sēra saturs sapropelī variē no 0,3 līdz $6,3 \%$, un tas sapropelī atrodas sulfātu, sulfìtu, elementārā un organisko savienojumu formā [22], [34], [45], [58].

Pētot sapropel̦a nogulumus Baltkrievijas ezeros Červonojes, Sudobl̦es un Sergejevskojes - A. Goncovs un V. Loženicina noteica to elementu sastāvu: augstākais C (59,3\%) un $\mathrm{H}(7,4 \%)$ saturs novērots kalıksainajā sapropelī, augstākais O (32,0\%) saturs - silīcija dioksīdu saturošā, N (4,8\%) organiskajā sapropelī [60].

Pēc elementu sastāva saldūdens sapropelis ir līdzīgs humusvielām. Sāḷo ezeru nogulumi satur mazāk organisko vielu (nosacīti pieņemts $\leq 10 \%$ ); šajās ūdenstilpēs flora un fauna ir nabadzīgāka un mineralizācijas procesi notiek ātrāk [55], [61].

Jāatzīmē, ka dažāda tipa sapropel̦a kopējais organisko vielu daudzums (\%) ir atšķirīgs: organiskajā sapropelī $70-93 \%$, silikātu un karbonāta - 15 - 70\%, jauktajā - 15 - 70\% [12], [18] - [20].

\section{B. Sapropeļa sastāvā ietilpstošie savienojumi}

Sapropelis ir degtspējīgs izraktenis, kas sastāv no dažādiem ķīmisko grupu savienojumiem [58]. Par svarīgāko sapropel̦a ķīmisko raksturojumu M. Ponomarjova uzskata tā organiskās masas sastāvu. Šādiem pētījumiem ir ne tikai teorētiskā, bet arī liela praktiska nozīme. Atkarībā no dažādu grupu savienojumu satura sapropel̦a organiskajā masā tiek izvēlēts maksimāli racionāls virziens tā praktiskai izmantošanai [55].

Apjomīgākie pētījumi šajā jomā bija veikti Baltkrievijas teritorijā [36], Latvijas divu sapropel̦a atradṇu organiskās masas sastāvu izpētīja V. Kalniņa [15].

Dažādu savienojumu grupu izdalīšana no sapropẹ̦a organiskās masas ir balstîta uz to frakcionēšanas metodēm, tāpēc atkarībā no šīm metodēm radās vairākas klasifikācijas un atsevišķ komponentu sastāva variācijas. [58]:

V. Rakovskis sapropeḷa organiskās masas sastāvā izdalījis

- bitumus;

- ūdenī šks̄istošas vielas;

- vielas, kas viegli hidrolizējas, tai skaitā humīnskābes un fulvoskābes;

- celulozi;

- atlikumu, kas nehidrolizējas.

V. Bakšejevs iedala sapropeḷa organiskās vielas: bitumos, oglūudeņražos, sapropel̦a skābēs un atlikumā, kas nehidrolizējas [54].

Latviešu zinātnieks N. Brakšs, pētot organisko sapropeli, izdalīja 5 vielu grupas un noteica to organiskās masas svārstības, līdzīgi kā to darīja Baltkrievu zinātnieki [22]:

- A $(3,4-10,9 \%)$ un C $(2,1-6,6 \%)$ bitumi;

- ūdenī šks̄istošas vielas $(2,4-13,5 \%)$;

- hemiceluloze $(9,8-52,5 \%)$;

- humīnskābes $(11,3-37,6 \%)$ un fulvoskābes $(2,1-3,5 \%)$;

- atlikums, kas nehidrolizējas (5,1 - 22,6 organisko vielu masa \%).

O. Hohlova izdalīja: bitumus un lipīdus (vielu grupu izdala ar nepolāriem šķīininātājiem - benzols, dietilēteris, u.c.), humusvielas (izdala ar sārmu), vielas, kas viegli hidrolizējas (izdalītas ar $2 \% \mathrm{HCl}$ hidrolīzi), vielas, kas grūti hidrolizējas (izdalītas ar $80 \% \quad \mathrm{H}_{2} \mathrm{SO}_{4}$ hidrolīzi) un atlikumu, kas nehidrolizējas (paliek pēc secīgas visu frakciju izdalīšanas) [12].

Saldūdens sapropeli pēc komponentu sastāva E. Kazakovs iedalīja [34]:

- nabadzīgs ar lipīdiem (1\%) un proteīniem (parasti 4 $9 \%$, atsevišksos gadījumos $9-12 \%$ );

- relatīvi nabadzīgs ar bitumiem ( $\mathrm{C}$ bitumi $1-3 \%, \mathrm{~A}$ bitumi $6-11 \%$ ar vasku pārsvaru).

G. Jevdokimova un M. Lopotka [20], [44], pētot sapropel̦a bitumus, konstatēja, ka tie ir identiski kūdras bitumiem pēc vairākiem rādītājiem:

- bagāti ar ogl̦ūdeņražiem (25 - 40\%) un organiskajām skābēm (līdz 13\%);

- ar zemu lignīna saturu $(2-8 \%)$;

- ar nelielu neizšķīdušo organisko vielu atlikumu $(2-18 \%)$.

Tomēr sapropelī atšksirībā no bitumiem, kas izdalīti no kūdras, ir lielāka taukskābju molekulārā masa, un, glabājot sapropeli uz lauka 2 mēnešus, sapropeḷa bitumu koncentrācija pieaug 1,5 reizes [62]. 
Salīdzinot sapropeḷa k̦īmisko savienojumu grupu sastāvu un koksēšanas rezultātus, tika noskaidrots, ka nosacītās vielu grupas (humīnskābes, atlikums, kas nehidrolizējas u.c.), kas tika izdalītas komponentu sastāva analīzes rezultātā no dažādām atradnēm, pēc savas ķīmiskās dabas nav identiskas un ir atkarīgas no sapropel̦a veidotājorganismu īpašībām (planktons, augstākie augi, ārpus ūdenstilpes atnestās humusvielas) un to pārvērtību nosacījumiem [22].

Bitumi (lipīdi) ir organiskās vielas, kuras no sapropeḷa ekstrahē ar dažādiem organiskajiem šksīdinātājiem. Bitumu sastāvu raksturo taukskābju, steroīdu, karotinoīdu, parafīnu, vasku un glicerīnu saturs [59].

Sapropel̦a bitumu komponentēm tiek veltīta īpaša uzmanība, jo tām piemīt augsta baktericīda, bakteriostatiska un antioksidanta aktivitāte. Daudzi pētījumi ir vērsti uz vieglām un efektīvām metodēm šo vielu iegūšanai no sapropeļa [63], [64]. Mazpārveidoto organisko vielu sastāvā ir pelō̄du (ārstniecisko dubḷu) bitumi, kuru sastāvā ir liels divkāršo saišu un funkcionālo grupu skaits - karotīni, fosfolipīdi, nepiesātinātās taukskābes un spirti.

M. Lopotko pētījumos sapropelim tika noteikts zems bitumenu saturs $2-7 \%$ no organiskās masas [65], bet V. Pozdnjaks, izdalot bitumus ar benzīnu un spirta-benzola maisījumu, ieguva 4,3 - 9,9\% [58]. Mazpelnainos un vidēji pelnainos nogulumos bitumu daudzums nepārsniedz 5\%, retos gadījumos 6,0 -8,1\% no organiskās masas [55].

Bitumu daudzums sapropel̄i ir zemāks nekā kūdrā [66], sapropeḷa bitumi sastāv pārsvarā no piesātinātiem savienojumiem. No kūdras sapropel̦a bitumi atšķiras ar zemāku skābuma pakāpi un zemāku pārziepjošanos, tas norāda, ka to sastāvā ir neitrāla rakstura savienojumi ogl̦ūdeņraži [44].

Pēc N. Kurmiševas datiem [56], glabājot sapropeli uz lauka 2 mēnešus, bitumu daudzums tajos pieaug divas reizes, bet, glabājot sapropeli nostādinātājos 1 gadu to daudzums samazinās 1,5-2 reizes. Taču nostādinātājos glabāta sapropeḷa virsēja slāņa paraugos bitumu daudzums pieaug $6,0-7,6 \%$, kas ir analogas izmaiñas sapropelim, kas tiek glabāts uz lauka un kur attīstās attiecīga mikroflora. Glabājot sapropeli nostādinātājos 5 gadus, bitumu daudzums pieaug, bet nesasniedz sākotnējos rādītājus. Vairākkārtīga sapropeḷa izsaldēšana un atkausēšana uz bitumu frakcijām ietekmi neatstāj [12].

Vairāki zinātnieki [67] - [69] atklāja, ka ezera un purva nogulumi satur karotinoīdus, kuru avots ir bioproducentu atliekas. E. Titovs uzrāda, ka sapropel̦a karotinō̄di pārsvarā sastāv no $\beta$ - karotīna (A provitamīns). $\beta$ - karotīna daudzums Urālu karbonāta sapropelī sasniedz $30 \mathrm{mg}$, silikātu sapropelī ap $20 \mathrm{mg}$ uz $1 \mathrm{~kg}$ sausās masas [11]. P. Anderona un B. Vimbas pētījumi uzrādīja, ka dažās Latvijas sapropeḷa iegulās karotīna daudzums sasniedza $178 \mathrm{mg} / \mathrm{kg}$ sausās masas [70].

E. Lederers no ezeru sedimentiem izdalīja karotīnu, 2 ksantofilus un 11 neidenficētus karotinoīdus [71]. Nakuru ezerā organiskos nogulumos, kas atrodas Āfrikā, tika atrasts karotinoīds - rodoviolascins, kas ir purpuru baktēriju pigments [72]. J. Valentains konstatējis $\alpha$ - un $\beta$ - karotīnu 11 tūkstošus gadu vecos ezera nogulumos [73]. D. Fokss atrada $\alpha-$ un $\beta-$ karotīnu jūru sedimentos [74]. Kopumā dažādos pētîjumos ūdenstilpju nogulumos zinātnieki identificēja ap 20 dažādu karotinō̄du [55], kuri, pēc J. Valentaina domām, ir praktiski identiski gan ezeru, gan jūru nogulumiem [73].

Sapropelim raksturīgs zems ogl̦ūdeņražu saturs, jo sapropel̦a veidošanās laikā aktīvi norisinās ogl̦ūdeņražu sabrukšana līdz ogl̦skābai gāzei un humifikācija ar humusvielu veidošanos aminoskābju kondensācijas reakcijās. Vidējs hemicelulozes daudzums sapropel̦a organiskajās vielās ir 6$25 \%$, bet celulozes $1-8 \%$ [17]. Sapropelis ir nabadzīgs ar celulozes komponentiem - vidēji 1 - 2\%. Sapropel̦a ogḷūdeņraži sastāv $\geq 80 \%$ no hemicelulozes, tāpēc tos iespējams izmantot lopbarības piedevās un mēslojumā [75].

Sapropel̦a humusvielu sastāvs un īpašības nosaka tā svarīgākās īpašības: bioloǵisko aktivitāti, bioḳimisko stabilitāti, salipšanas spēju u.c. Atkarībā no satura un specifiskās humusvielu attiecības, augsnē ienestais sapropelis var dažādi ietekmēt bioḳīmiskos procesus, augsnes struktūras veidošanos un iegūto lauksaimniecības produktu kvalitāti. Sapropel̦a humusvielas no augsnes humusvielām atšksiras ar augstāku ūdeņraža un oglekḷa attiecību un piesātināto aromātisko gredzenu trūkumu [59]. Sapropel̦a humusvielas ir reducētākas, un tām piemīt lielāka aktivitāte nekā augsnes humusvielām.

Sapropel̦a humusvielu sastāvā ietilpst humīnskābes, fulvoskābes un himatomelānskābes.

Humusvielu izdalīšana no sapropel̦a minerāliem un organiskiem savienojumiem parasti tiek veikta pēc klasiskās Tjurina shēmas, kuru viņš izmantoja, pētot augšņu ķīmisko sastāvu [59]. Pētāmie paraugi tiek dekalcificēti, lai atdalītu karbonātus. Kaut gan š̄ metode ir vienkārši pielietojuma, dabīgo polimēru šḳīināšanā un izgulsnēšanā nav iespējams piln̄igi atdalīt visus mazmolekulāros komponentus og̣̦ūdeņražus, spirtus, aminoskābes, tāpēc atkarībā no pētāmā objekta un mērķiem, š̄i shēma bieži tiek modificēta [62] - [64].

Humīnskābes ir lielākā organisko vielu grupa, tām ir tumši brūna krāsa. Tās parasti izdala no nogulumiem ar sārmainiem šķīinātājiem un nogulsnē skābā vidē (pH 1 - 2).

Zemo un augsto purvu kūdras humīnskābēs oglekḷa daudzums mainās no 57,7 - 64,2\%, bet ūdeñradis - 4,3 - 5,4\% robežās [44]. Sapropelī esošās humīnskābes pēc elementu sastāva atškiras no kūdrā esošajām ar to, ka ūdeņraža sastāvs tajās ir augstāks nekā kūdras humīnskābēs, kas liecina par taukskābju klātbūtni. E. Kazakovs uzskata, ka lielāks slāpekḷa saturs sapropel̦a humīnskābēs liecina par humīnlīdzīgiem piemaisījumiem - melanoīdiem, kas veidojušies, kondensējoties olbaltumvielu sabrukšanas vielām (aminoskābēm un ogḷūden̦ražu sabrukšanas rezultātā veidotām vielām) [34].

Dažāda tipa sapropeḷa humusvielas atšķiras pēc elementu sastāva, funkcionālo grupu un og̣̦ūdeņražu fragmentu satura, ko nosaka sapropeli veidojošās vielas un konkrētās ūdenstilpes humifikācijas apstākḷi [76].

Sapropel̦a humusvielas un bitumi veido organominerālos savienojumus ar augstu neorganisko elementu koncentrāciju, tāpēc tiem ir augsta pelnainība [64]. 
Sapropelī tika atrasti arī ūdenī šks̄istoši vitamīni: askorbīnskābe (C), B grupas vitamīni - tiamīns (B1), riboflavīns (B2), pantotēnskābe (B5), piridoksīns (B6), folskābe (B9) un ciānkobalamīns (B12). Lielos daudzumos konstatēti arī taukos šks̄istošie vitamīni - tokoferols (E), D un P vitamīni [27].

Ciānkobalamīnu (B12 vitamīns) saturošam sapropelim, kas koncentrējas sapropel̦a augšējā slān̄̄ (līdz $1 \mathrm{~m})$, ir augsta vērtība kā lopkopības barības piedevai, jo tas stimulē metionīna biosintēzi organismā. Eksperimentālu pētījumu rezultātā tika konstatēts, ka vitamīns B12 veicina daudzu mikroorganismu aktivitāti dūņu nogulumos, tam ir liela nozīme asins ķermenīšu veidošanās un olbaltumvielu apmaiṇas procesos [77], tomēr, jāṇem vērā, ka sapropeḷa izsaldēšana vai ilgstoša glabāšana samazina ciānkobalamīna saturu.

Lietuvas sapropelī tika atrasts augsts B12 vitamīna saturs [78], savukārt Latvijas sapropelī riboflavīna saturs nepārsniedza $25 \mathrm{mg} / \mathrm{kg}$ mitra sapropeḷa, bet folijskābe - 42$64 \mathrm{mg} / \mathrm{kg}$ no sausas masas [79].

\section{Sapropeļa minerālo vielu ķīmiskais sastāvs}

Sapropel̦a minerālo sastāvdaļu kopums ir svarīga diagnosticējoša pazīme tā klasifikācijā. Minerālo komponentu veidošanās ezera gultnes nogulumos ir saistīta ar terigēno noteci un tai sekojošu minerālu sedimentāciju un ūdenstilpē izšķīdušo minerālu jonu bioloǵisko un ķīmisko nogulsnēšanos. Parasti terigēnās noteces minerāli ir kvarcs $\left(\mathrm{SiO}_{2}\right)$, dolomīts $\left(\mathrm{CaMg}\left(\mathrm{CO}_{3}\right)_{2}\right)$, silikāti un alumosilikāti (laukšpati, hidrovizla, hlorīti, kaolinīts, u.c). Bioķīmisko procesu rezultātā ūdenstilpes sapropelī uzkrājas kalcīts un aragonīts (karbonāti $\mathrm{Mg}, \mathrm{Ca}, \mathrm{Sr}, \mathrm{Ba}, \mathrm{Fe}, \mathrm{Mn})$, pirīts $\left(\mathrm{FeS}_{2}\right)$, ğipsis $\left(\mathrm{CaSO}_{4} \cdot 2 \mathrm{H}_{2} \mathrm{O}\right)$, hematîts $\left(\mathrm{Fe}_{2} \mathrm{O}_{3}\right)$, markazìts $\left(\mathrm{FeS}_{2}\right)$ un vivianīts [15], [75], [80].

No dzelzs minerāliem dominē brūnie oksīdi - trīsvērtīgie dzelzs oksihidroksīdi, getīts un hidrogetīts $(\mathrm{FeOOH})$, retāk dzelzs pirīts un fosfâti, reti - siderīts $\left(\mathrm{FeCO}_{3}\right)$. Dzelzs sulfăta heptahidrāta minerāli ir raksturīgi sapropel̦a slāņa dzil̦ākajai dal̦ai griezumā, kur veidojas siderīts un dal̦a dzelzs fosfātu. Tas ir saistīts ar organisko vielu sadalīšanos un reducēšanās apstākliiem. Dzelzs fosfāti, tāpat kā dzelzs brūnie oksīdi, ir izplatīti visos sapropel̦a genētiskajos tipos - dzelzs fosfātu saturs palielinās līdz ar karbonātiskuma samazināšanos. Šo fosfātu saturs karbonātiskā sapropelī ir 0,4\%, jauktā sapropelī- $-0,8 \%$, bet silīcija oksīdus saturošā $-1,4 \%$. Kalcija fosfāti sapropelī sastopami apatīta formā, dzelzs fosfāti vivianīta formā.

Minerālo nogulumu veidošanās raksturīga leduslaikmeta beigu posmam. Holocēna laikmeta organominerālā sapropeḷa minerālās daḷas veidošanās dinamiku noteica ūdenstilpes caurplūdums, bet mūsdienās - sateces baseina teritorijas izmantošana lauksaimniecības vajadzībām. Reǵionālās novirzes attiecība $\left(\mathrm{SiO}_{2}>\mathrm{Al}_{2} \mathrm{O}_{3}>\mathrm{Fe}_{2} \mathrm{O}_{3}, \mathrm{~K}_{2} \mathrm{O}>\mathrm{Na}_{2} \mathrm{O}\right)$ var būt saistīta ar iekšējo nogulumu materiāla konversiju [15], [80].

Integrētā līmen̄̄ sapropeḷa minerālais sastāvs tiek novērtēts pēc pelnainības, ieskaitot $\mathrm{CO}_{2}$ karbonātus $\left(\mathrm{A}_{\mathrm{c}}\right)$ vai starpības $\left(100 \%\right.$ - zudumi pēc izkarsēšanas $\left.900-1000^{\circ} \mathrm{C}\right)$. Lielāko pelnu dalı sastāda dzelzs un kalcija fosfāti - pelnu sastāvā stabilo oksīdu formā ne mazāk par vienu 1\% sastāda: $\mathrm{SiO}_{2}$, $\mathrm{Fe}_{2} \mathrm{O}_{3}, \mathrm{Al}_{2} \mathrm{O}_{3}, \mathrm{CaO}, \mathrm{MgO}, \mathrm{Na}_{2} \mathrm{O}, \mathrm{K}_{2} \mathrm{O}, \mathrm{P}_{2} \mathrm{O}_{5}$ [81]. Nogulumus ar pelnainību lielāku par $85 \%$, Krievijas, Lietuvas un Latvijas zinātnieki uzskata par ezeru nogulumiem ar augstu pelnainību, bet citu valstu pētnieki par sapropeli pieņem nogulumus, kuru pelnainība sasniedz līdz pat 98\% [42].

E. Kazakova ķīmiski tehnoloǵiskie dažādu dabas zonu (skujkoku, jaukto koku un lapu koku meži, stepes un to apakšzonas) sapropel̦a pētījumi parādīja, ka pelnainība sapropelī var mainīties lielā diapazonā: no 8,9\% līdz 93,0\% lielākais pelnu saturs ir stepju zonas sapropelī [34].

Tika noskaidrots, ka pelnainība paaugstinās, ilgi glabājot sapropeli nostādinātājos, piemēram, 3 gadus glabātā N̦erova atradnes sapropel̦a pelnainība pieauga no 64\% līdz 70\% [12].

Silīcija komponentu uzkrāšanās likumsakarības dažādos sapropeḷa tipos norāda uz to, ka suspensijas sastāvā silīcijs nonāk no kramaļgú atliekām un uzkrājas baktērijās; organiska tipa sapropel̦a pelnu galvenais komponents ir $\mathrm{SiO}_{2}$, pārējie elementi ir loti nelielos daudzumos. Nozīmīgas atšķirības organiskā sapropeḷa pelnos netika atrastas [12], [75].

Jaukta tipa sapropelis satur nedaudz vairāk pelnu, taču to saturs ir identisks organiskajam sapropelim, ja pelnos dominē $\mathrm{SiO}_{2}$. Ja jaukta tipa sapropelī ir karbonāti, tad $\mathrm{CaO}+\mathrm{MgO}$ saturs ir 7,9-16,6\% - tāda sapropel̦a pelnainība var sasniegt 60\%. Silikātu sapropelī silīcija oksīda saturs brīvā formā kvarcs un kvarcs dažādu silikātu un alumosilikātu formā - ir no $30,3 \mathrm{līdz} 70 \%$ [15].

Kramaļgu sapropelis satur amorfas silīcijskābes, kas ir vairāk pieejamas augiem [19], taču silīcija pārpilnība nerada toksisku iedarbību uz augiem [42].

Galvenais minerālais komponents karbonāta sapropelī ir kalcija karbonāts. Kalcija minerālā forma ir dolomīts, mālaini ar dzelzs piejaukumu karbonāta agregāti, kā arī biogēnas izcelsmes kalcīts. Karbonāti ir sastopami amorfos un koloidālos savienojumos, kuriem ir organiska izcelsme un augsta mobilitātes pakāpe: 20-50 \% no kopējā satura [20]. $\mathrm{CaO}$ saturs karbonāta sapropelī sasniedz 90\%, organiskajā sapropelī - 0,4-5,25\%, pelnos, pārrēķinot uz sauso masu: jaukta tipa 0,9-12,5\%, silikātu - 1,2-12,3\%, vidēji dažādos sapropel̦a tipos $\mathrm{CaO}$ ir no $0,7 \mathrm{li} \mathrm{dz} 37 \%$.

Eitrofās ūdenstilpēs kalcīta nogulsnēšanos veicina augu, kas saista $\mathrm{CO}_{2}$, fotosintēze un organismi (moluski, čaulu vēzī̌si), kas uzkrāj kalciju šūnās dzīves laikā. Paaugstinoties sulfātu daudzumam ūdenī, var notikt sulfātu redukcija, kuras rezultātā rodas kaļķainas nogulsnes. Kalcija klātbūtne ūdenstilpē paātrina organisko vielu sadalīšanos un paaugstina kalcija saturu nogulumos.

Paaugstināta skābuma dēḷ, ko izraisa paaugstināts $\mathrm{CO}_{2}$ saturs organisko vielu sabrukšanas procesā, karbonāti var ar̄̄ nenogulsnēties [7].

L. Kirejčeva un O. Hohlova noteica, ka ilga sapropel̦a glabāšana nostādinātājos, sevišķi stirpās, paaugstina karbonātu saturu, jo, mineralizējoties organiskām vielām, no sapropeḷa organominerālā kompleksa atbrīvojas kalcija oksīdi, bet viens no organisko vielu oksidēšanas produktiem ir ogl̦skābā gāze. Tas nozīmēe ka organiskās vielas sastāvā esošais ogleklis 
pārvēršas par karbonātu oglekli. Tas ir raksturīgs sapropelim ar lielu organisko vielu saturu - oglekḷa daudzums, kas tiek saistīts karbonātos, pieaug līdz 5 reizēm. Karbonātos saistītā oglekḷa daudzumu sapropelī var izmantot kā sapropel̦a mineralizācijas rādītāju un izmantot šīs izmaiņas sapropeḷa mineralizācijas pakāpes noteikšanai aerobos apstākḷos [12].

Kopējais dzelzs daudzums sapropelī sastāda 2-18\%, reti $28 \%$. Nogulumos dzelzs parasti nonāk koloidālo organominerālu savienojumu formā kopā ar māla dal̦in̄ām. $\mathrm{Fe}_{2} \mathrm{O}_{3}$ organiskā sapropelī parasti sastāda 4,9\%, silīcija dioksīdu saturošā - 5,6\%, karbonāta - 4,7\%, jaukta tipa sapropelī 8,4\%, taču dažreiz šis rādītājs var sasniegt 30 - 50\% no pelnu apjoma [43]. Lielos daudzumos sevišķi mobilās formās dzelzs uz augiem iedarbojas nomācoši [20]. Ūdens vidē notiek intensīva minerālu sairšana, kas paaugstina dzelzs mobilo formu daudzumu, kas var sastādīt līdz $80 \%$ no dzelzs kopējās masas [45]. Žāvējot un vēdinot gaisā dzelzs savienojumu reducēšanās un mobilitāte samazinās un daḷa hidratētu formu pārvēršas kristālos. Gaissausos paraugos mobilie dzelzs savienojumi nepārsniedz 1\% [20], [75].

Alumīnija saturs sapropel̄̄ mainās 0,3 - 11\% robežās, parasti tas ir $2-4 \%$ robežās, un tā augstākas koncentrācijas sastopamas silikātu sapropelī, jo tas satur mālainos minerālus. Sapropel̦a pētījumi Baltkrievijā neatklāja amorfas alumīnija formas, kas ir augsti toksiski augiem [15], [75].

Mikroelementu stratifikācija ezeru nogulumos ir detalizēti izpētîta Baltkrievijas un Tjumeñas ezeru nogulumu pētījumos. Nogulumu virsējos slāņos ir augsts mikroelementu summārais daudzums, zemāk viscaur notiek to samazinājums un zemākos slān,os stabils pieaugums. Tas ir saistīts ne tikai ar sapropeļa tipa izmain̄ām, bet arī ar k̦īmisko elementu migrāciju uz zemākiem slāņiem, to reducēšanas rezultātā sapropeļa slānī. Elementu pieaugums sākas 5-7 m dziḷos slāņos, kur norisinās reducēšanās. Sapropelis satur tādus mikroelementus kā Mn, $\mathrm{Co}, \mathrm{Mo}, \mathrm{Cu}, \mathrm{Ni}$ u.c., sevišksi bagāts ar tiem ir silikātu sapropelis, bet nabadzīgs - karbonātu. Organiskā un jauktā tipa sapropelī mikroelementu rādītāji ir vidēji. Tādu elementu kā Mn, Co, B, Zn, Mo daudzums ir l̦oti dažāds. Summārais mikroelementu saturs $\mathrm{B}, \mathrm{Ni}, \mathrm{Cu}, \mathrm{Co}, \mathrm{V}, \mathrm{Mo}, \mathrm{Cr}$ ir no $20 \mathrm{li} d z$ $150 \mathrm{mg} / \mathrm{kg}$ sausnā, bet Ti, Mn, Zn - 200-2000 $\mu \mathrm{g} / \mathrm{kg}$. Pēc mikroelementu koncentrācijas samazinājuma sapropeli var iedalīt: silikātu, jaukta tipa, organiskais, karbonātu [20].

Svins ir sastopams daudzu minerālu sastāvā - silikāti, haploīds, manganīts, ferīts, karbonāti. Svina mobilitātes procesā augsnē svarīga loma ir humusvielām, kas adsorbē svinu organiski-minerālos kompleksos. Mūsdienu apstākḷos iespējami paaugstināts svina saturs pelogēnā rūpniecisku apgabalu ezeros, piemēram, Nero ezerā svina koncentrācija ir $12 \mathrm{mg} / \mathrm{kg}$, kas 10 reizes pārsniedz vidējo svina saturu organiskajos ezera nogulumos [7].

Bora savienojumi parasti ir viegli šķīstoši, tāpēc bors viegli izskalojas no augsnes un uzkrājas ūden,os. Vidējais bora saturs sapropelī ir $1,5 \mathrm{mg} / \mathrm{kg}$. Zemākas bora koncentrācijas atrodamas karbonāta sapropelī [42].

Titāns sapropelī uzkrājas minerālu formā (rutīts, ilmenīts, leikoksēns u.c.), tāpēc mobilās formas iespējamas tikai stipru skābju šksīdumos.
Hroma saturs ezera nogulumos nepārsniedz $10 \mathrm{mg} / \mathrm{kg}$. Tas atrodas oksīdu formā un izkliedētā veidā, aizvietojot silikāta savienojumos alumīnija un dzelzs jonus. Silīcija dioksīda un kal̦ķa nogulumi satur visvairāk šī elementa.

Cirkonijs tāpat kā titāns sastopams kristāliskos minerālos (cirkonijs), tā saturs vidēji sastāda $80 \mathrm{mg} / \mathrm{kg}$.

Fluors nokḷūst ūdenstilpēs ar deluviālo noteci mālaino minerālu formā, tāpēc silikātu sapropelī tā saturs ir 8$34 \mathrm{mg} / \mathrm{kg}$, bet karbonāta tipa nepārsniedz $12 \mathrm{mg} / \mathrm{kg}$ [42].

Jods uzkrājas organisko vielu nogulumos, nonākot tajos no ūdenszālēm. Akcesorā veidā sapropelī tika atrasta alva, arsēns, dzīvsudrabs un kadmijs, tomēr pētījumi uzrādīja, ka, iestrādājot sapropeli kā mēslojumu pat lielās devās (100 t/ha ar $50 \%$ mitrumu), tie nevar radīt augsnes piesārņojumu ar smagajiem metāliem [75]. Ezera nogulumu augstā sorbcijas spēja var veicināt to izmantošanu augšņu rekultivācijas nozarē [12].

\section{Sapropela sastāvā ietilpstošie dzīvie organismi un tā biologisk $\bar{a}$} aktivitāte

Biologisko komponenti saldūdens ekosistēmās veido hidrobionti, kuru dzīves cikls veicina aktīvu organisko vielu uzkrāšanos ekosistēmā sapropel̦a nogulumu veidā.

Pētījumi rāda, ka ezera sapropelī ir ārkārtīgi daudz mikroorganismu - 1 g svaiga sapropeḷa tā virsējā slān̄i ir 12 miljardi mikroorganismu. Dzil̦ākos slāņos, sākot no 0,6$1,0 \mathrm{~m}$ no ezera gultnes virsmas, mikroorganismu skaits samazinās [82].

Sapropelī tika atrasti mikroorganismi, kas izdala antibiotikas, kuras ir antagoniskas virknei patogēnu saprofîtisku mikroorganismu. Šì sapropeḷa īpašība ir nozīmīga sapropel̦a izmantošanai balneoloǵijā [83].

Antibiotikas un sulfanilamīdus sapropelī sintezē sēnes un aktinomicētas, vitamīnus - baktērijas un aḷges. Azobaktērijas veicina slāpekļa pāriešanu augiem pieejamā formā.

Dažādas baktēriju un ūdens sēṇu grupas ir specifiski organisku vielu destruktori (sadala atmirušos hidrobiontus līdz atsevišķiem fragmentiem) un piedalās biok̦īmiskos procesos sapropel̦a sekundāru organisko vielu sintēzē (humifikācijā) [42].

Sapropeḷa sastāvā esošie dz̄ivie organismi piedalās dažādos procesos vielu pārveidošanā, ne tikai veidojot sapropel̦a nogulumus, bet arī reǵenerējot un konservējot tos. Pateicoties mikroorganismiem, sapropelī var norisināties mineralizācija un organisko vielu sintēze, tie nosaka dažādu gāzu (sērūdeņradis, amonjaks, metāns u.c.) sastāvu un to daudzumu nogulumos. Nogulumos uzkrājas bioloǵiski aktīvas un antibakteriālas vielas, kurām ir liela nozīme balneolog̣ijā. Mikroorganismu veidotās bioķīmiskās vielas nosaka arī dažas fiziski - ķ̄īmiskas īpašības sapropelī.

Vielu aprites ciklā ūdenstilpēs piedalās tikai organiskas un minerālas vielas no sapropel̦a nogulumu virsējiem slāņiem. Dziḷākos slāņos mikroorganismu aktivitāte apstājas, tāpēc arī organisko vielu sadalīšanās norit ļoti lēni.

Latvijā 1965. gadā T. Stūris [84] izpētīja Kaņieru un Babītes ezeru mikrofloru, lai noskaidrotu izpētītā sapropel̦a potenciālās izmantošanas iespējas medicīnā. Pētījumos tika 
konstatēts, ka mikroorganismu izplatība un biok̦īmiskā aktivitāte ir tieši atkarīga no sapropel̦a slāṇa dzil̦uma un gadalaika. Mikroorganismu augstākā aktivitāte tika novērota ezera neaizaugušās daļas nogulumos no 0,1 līdz $0,5 \mathrm{~m}$ dziļumā, kur atrodas lielākais viegli hidrolizējamo organisko vielu daudzums, taču aktivitātes sarukums novērojams $1,0 \mathrm{~m}$ dziļumā. Kaṇieru un Babītes ezeru sapropelī tika konstatētas vairākas baktēriju grupas: dūṇu veidojošas baktērijas, sēra apritē piedalošās baktērijas, organisko un neorganisko vielu pārveidotāji, sērūdeṇraža producētāji.

\section{SAPROPEL̨A RESURSI LATVIJĀ}

Sapropel̦a izplatība pasaulē ir izpētīta samērā nevienmērīgi. Samērā pilnīgi dati par sapropeḷa nogulumu izplatību ir pieejami par Latvijas, Lietuvas, Igaunijas, Baltkrievijas, Ukrainas, Krievijas Centrālās Eiropas daļas teritorijām [27].

No Tomina un Fomina sapropel̦a pētījumiem var spriest, ka sapropel̦a uzkrāšanās dažādās pasaules dạ̦ās ir nevienmērīga un atšksirīga, lielā mērā tā ir atkarīga no teritorijas ezerainības. Vislabvēlīgākā zona sapropeḷa veidošanai ir mežu teritorijas, turpretim mūžīgā sasaluma teritorijas, kalnaini apvidi un apvidi, kur atsedzas pamatklintājs, nav tik piemērotas sapropel̦a nogulumu ǵenēzei. Apjomīgāki sapropel̦a nogulumu slāņi atrodas seklu, aizaugušu ezeru un purviem bagātos līdzenumos, kā arī lielu upju ielejās [13].

Sapropeḷa atradņu meklēšanas darbos, kas norisinājās laikā no 1990. gada līdz 2000. gadam, tika apsekoti daudzi ezeri visā Latvijā, izņemot Jelgavas rajonu. N̦emot vērā iepriekš veiktos sapropeḷa atradņu izpētes darbus, kopumā Latvijā ir apsekoti 1126 ezeri, no tiem 655 ezeri ir atzīti par rūpnieciskas nozīmes sapropel̦a atradnēm. Pēc apjoma lielākie sapropel̦a krājumi ir Ludzas, Rēzeknes un Rīgas rajonā (sk. 2.attēlu). Te sapropel̦a apjomi ezeros ir 98 358, 98240 un 86573 tūkstoši $\mathrm{m}^{3}$ attiecīgi. Pēc masas lielāki sapropel̦a krājumi ar mitrumu $60 \%$ ir Rīgas - 38609 tūkst. t, Valmieras - 20976 tūkst. t un Rēzeknes rajonā - 20226 tūkst. t. Šādas atškirības starp sapropel̦a krājumu apjomu un masu rodas sapropẹ̦a tipu dažādības un atšķirīgā sastāvā dēḷ. Piemēram, Rīgas un Liepājas rajonos dominē silikātu sapropelis, kas ir salīdzinoši smags, sākotnēji satur mazāku mitruma daudzumu, izžūstot mazāk sarūk. Iemesls, kāpēc Liepājas rajonā ir vidēji sapropel̦a krājumi, n̦emot vērā, kā Liepājas un Rīgas ezeru vecums ir aptuveni vienāds, ir tāds, ka šajā rajonā ir samērā zema ezerainība, savukārt Rīgas rajonā ezeru ir daudz. 10 rajonos sapropel̦a krājumu apjoms ir zemāks par 20000 tūkst. $\mathrm{m}^{3}$. Viszemākie sapropel̦a resursi ir Bauskas rajonā, tie sastāda tikai 645 tūkst. $\mathrm{m}^{3}$ vai 129 t ar mitrumu $60 \%$.

\section{SAPROPEĻA IZMANTOŠANAS IESPĒJAS}

Sapropelim, tāpat kā kūdrai, ir l̦oti plašas izmantošanas iespējas. To var izmantot praktiski jebkurā tautsaimniecības jomā, taču tā lielā dažādība un zemais izpētes līmenis traucē racionāli gūt gaidāmos rezultātus. Latvijā sapropeḷa izmantošana ir plaši pazīstama lauksaimniecībā kā mēslojums un lopkopībā kā dzînnieku barības piedeva, taču zinātne šim derīgajam izraktenim ir atradusi arī citas izmantošanas iespējas (sk. 3.attēls).

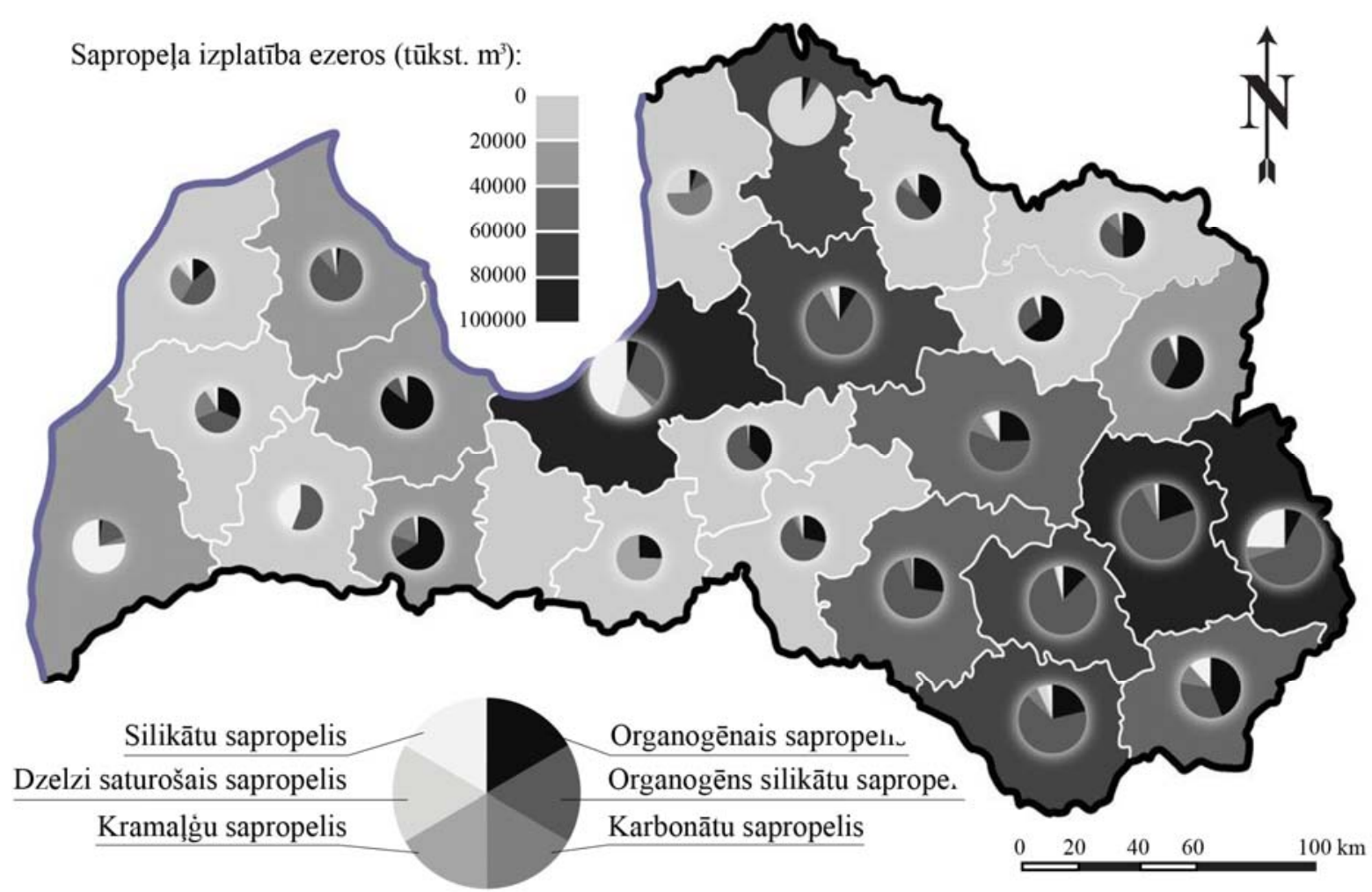

2. att. Sapropeḷa izplatība Latvijas rajonos pēc resursa daudzuma un tā tipiem. Autoru sastādīts, izmantojot [14]. 


\section{SAPROPELIS}

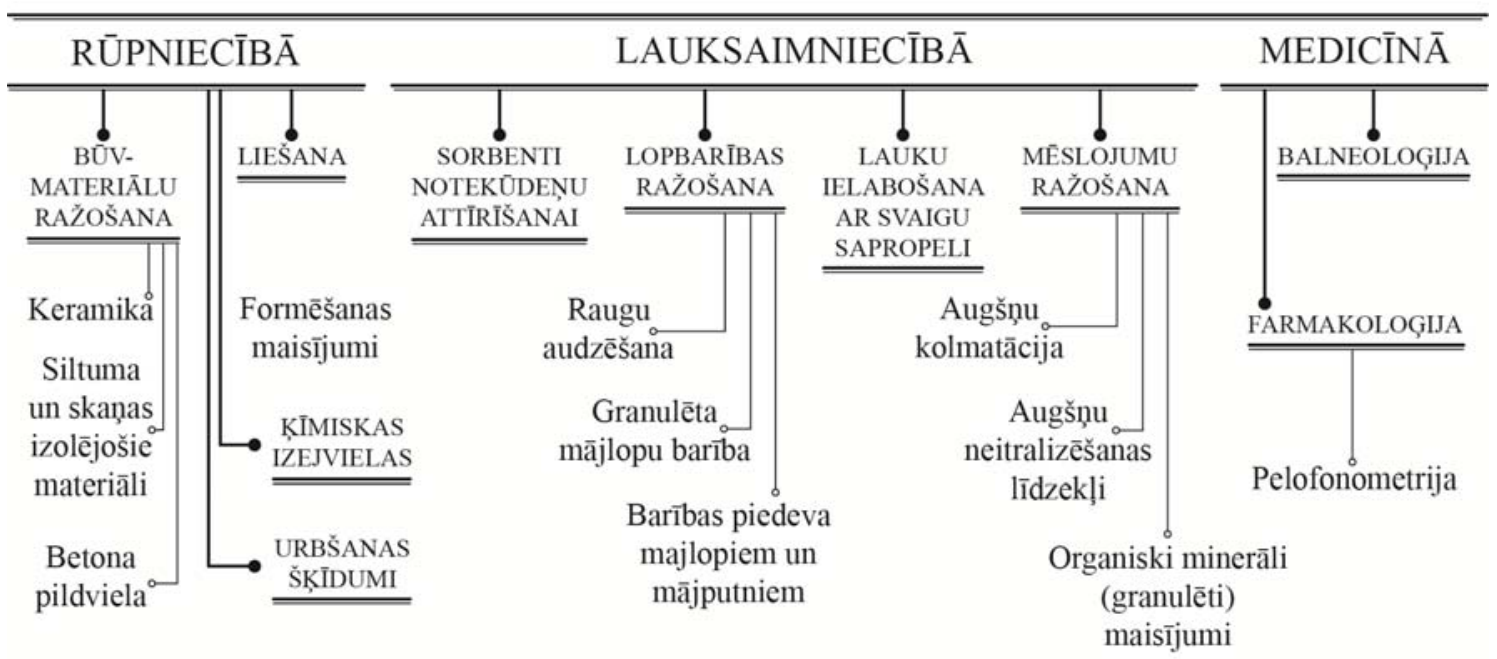

3. att. Sapropẹ̦a iespējamā izmantošana [33].

Par vērtīgāko sapropeli tiek uzskatīts organiskais sapropelis. Šim sapropel̦a tipam ir vairāk pielietošanas iespēju (sk. 4.attēls).

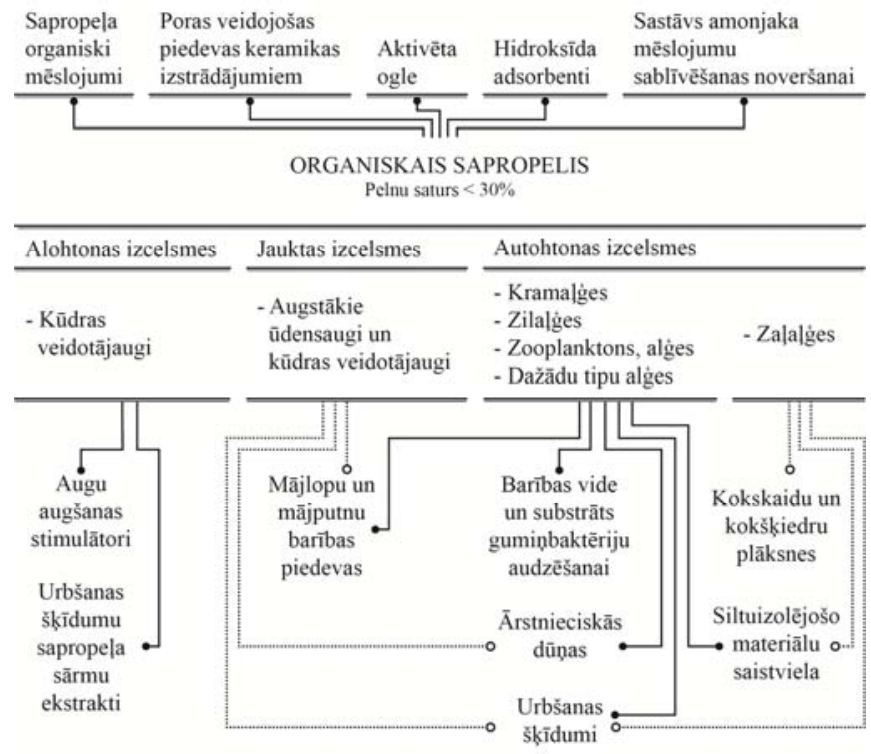

4. att. Organiskā sapropeḷa iespējamā izmantošana [85].

Sapropeḷa sārmu ekstrakti, tāpat kā brūnogḷu un kūdras ekstrakti, tiek izmantoti ǵeoloǵiskajā izpētē kā ekoloǵiski tīri urbšanas šks̄îdumi. Tie satur ūden̄̄ šķ̄īstošos sāļus un polivalentus metālus un tiek izmantoti humātu reaǵentos. Šie reaǵenti ir daļēji sintētiski materiāli, kas satur $\geq 40 \%$ humusvielas. Tos izmanto, lai ražotu dažādu tipu - emulsijas, paaugstinātu kalıksa u.c. - urbšanas šķīdumu viskozitāti un filtrāciju, naftas emulgêē̌anos emulsijas urbšanas šķīdumos. Augstās temperatūrās, lai novērstu urbšanas šķīidumu sabiezēšanu māla intensīvas peptizācijas (process pretējs koagulācijai, kad koloidālas sistēmas salipušas daļinas sairst) dēḷ, humātu reaǵentiem pievieno kālija dihromātu $\left(\mathrm{K}_{2} \mathrm{Cr}_{2} \mathrm{O}_{7}\right)$. Šo ekstraktu pielietojums pārsvarā ir ierobežots ar mineralizāciju, kas nevar būt lielāka par $2-3 \%$ (kālija humātu reaǵentiem $3-6 \%$ ). Humātu reaǵentiem ir zemas izmaksas un tos var izmantot ar jebkuriem citiem ķīmiskiem reaǵentiem, kurus pielieto urbšanas šķ̄idumu apstrādē [86].

1991. gadā Krievijā tika pētītas sapropel̦a izmantošanas iespējas augsti pelnainu degslānekḷu termiskās pārstrādes intensifikācijai, kas paaugstina iegūstamo sveķu un gāzu daudzumu un uzlabo to sastāvu. Šādai sapropeḷa izmantošanai der tikai organiskais sapropelis, kura optimālais pievienošanas daudzums degslāneklim ir $10 \%$. No šādi modificēta degslānekḷa var iegūt par 54\% vairāk sveķu, 4 reizes vairāk summāra fenolu daudzuma ar paaugstinātu sveksainu un ūden̄̄ šḳīstošu fenolu apjomu [87].

Latvijā 1957. gadā A. Kalniņa vadībā veiktie pētījumi Mežsaimniecības problēmu institūtā, Koksnes k̦īmijas institūtā un Latvijas Lauksaimniecības akadēmijā uzrādīja, ka ar sārmu apstrādātai organiska sapropel̦a frakcijai ar augsta dispersitāti $(<50 \mu \mathrm{m})$ un hidrolizētu vielu daudzumu piemīt laba salīmējoša un hidrofobizējoša spēja, kas var būt izmantota kā saistvielas piedeva kokšksiedru un lauksaimniecības atkritumu plātņu izgatavošanai, turklāt sapropeḷa tehniskie un fiziski mehāniskie rādītāji atbilst siltumizolējošo materiālu prasībām: blīvums - 150-300 kg/m3, izturības robeža - 0,4-3,0 MPa, ūdensuzsūce - 9-20\%, gaissausas masas siltumvadītspēja pie $25^{\circ} \mathrm{C}-0,048-0,075 \mathrm{~W}\left(\mathrm{~m}^{\circ} \mathrm{C}\right)$. Lielāko ieguldījumu sapropel̦a līmējošo īpašību izveidei sniedz slāpekli saturošas vielas, tajā skaitā brīvās aminoskābes, jo sapropel̦a sastāvu ietekmē humīnskābju molekulu struktūra. Ja sapropel̦a sastāvā palielinās humīnskābju daudzums, dal̦ā hidrolizējamo sastāvdal̦u palielinās perifēriskās daḷas molekulu sazarojums. Tas sekmē stipru saišu izveidošanos starp molekulām produkta izgatavošanas laikā. Pašas molekulas humīnskābēs paliek elastīgākas, apvelk formējamā materiāla cietās daļiņas, kas nodrošina materiāla stiprību un izturību [87]. Sapropeḷa saistvielas îpašības izmantojamas, izgatavojot celtniecībai noderīgus materiālus, gan karstajā apstrādē (līmspiedē 
paaugstinātā temperatūrā un spiedienā), gan aukstajā apstrādē - blietēšanas pan̄ēmiens [88].

J. Āboliņa veiktie pētîjumi celtniecības bloku un siltumizolējošo materiālu ražošanā no koku skaidām, mazsadalījušās kūdras un līdzīgām izejvielām. Kā līmviela labi der jēla sapropel̦a un $\mathrm{NaOH}$ maisījums, šos koka skaidu un kūdras maisījumus ar sapropeli vinšs nosauca par sapropel̦betonu. Tā kā viena no sapropeḷa svarīgākajām îpašībām ir tā koloīdā struktūra, tad sapropeļa organiskie kolō̄di spēj saistīt ievērojamu daudzumu ūdens. Pilna sapropel̦a mitruma ietilpība sasniedz līdz 97\% no sausas vielas masas. Tāpēc, lai samazinātu sapropel̦betona rukumu, sapropelim jālauj izžūt vismaz līdz $60 \%$ mitrumam un jāizmanto sausas pildvielas, kuras nesatur vairāk par $20 \%$ mitruma. Ar tādiem izejmateriāliem iegūst sapropel̦betonu, kas neuzrāda lielu rukumu, kā arī samazina žāvēšanas procesā patērēto enerǵiju un laiku. A. Gružāna ekonomiskie aprēķini uzrādīja, ka Latvijā sapropel̦betons varēja kḷūt par vienu no lētākiem un pieejamākiem celtniecības materiāliem valstī [89].

Lai pavairotu sapropeļbetona izturību pret dažādu sēnīšu iedarbību (bioloǵisko noturību), tam eksperimentos piejauca romāncementu (iegūst apdedzinot mālus), dzēstos vai nedzēstos kaļ̧̧us. Kā antiseptiķus izmēgināja: amonija silikofluorīdu, nātrija fluorīdu, antracēnelıı, vara naftenātu, koka darvu. Svarīgi, lai siltumizolācijas materiāls būtu pēc iespējas vieglāks, jo tad tas labāk aiztur siltuma caurplūšanu, līdz ar to nodrošina lielāku siltumietilpību. Izmantojot vieglas pildvielas, sapropel̦betons iegūstams ar nelielu tilpuma svaru $1 \mathrm{~m}^{3}$ sver $313 \mathrm{~kg}$ [88].

Sapropeļbetonam ir laba uguns noturība, tas pats nodziest un neturpina degšanas procesu, ja temperatūra ir zemāka par $380{ }^{\circ} \mathrm{C}$. Tādējādi sapropel̦betons ir izmantojams ne tikai kā siltumizolācijas materiāls; to var izmantot slodzi nenesošo šķērssienu, pārsegumu un sienu būvniecībā. Sapropel̦betonu var izmantot dzīvojamo un rūpniecības ēku, saldētavu sienu un pārsegumu, kā arī ierīču un caurul̦vadu (kuru temperatūra nepārsniedz $100^{\circ} \mathrm{C}$ ) siltuma izolācijai [90].

Tīrā veidā sapropeḷbetons virs $105^{\circ} \mathrm{C}$ sāk sadalīties un tādēl bez speciālas sagatavošanas nav lietojams temperatūrās augstākās par $100{ }^{\circ} \mathrm{C}$ [90]. Tas ierobežo sapropel̦betona plātnuu izmantošanu siltuma izolācijas vajadzībām. Tādēḷ ir nepieciešami atkārtoti eksperimenti un tehnoloǵijas pilnveidošana, lai panāktu iespējami lielāku pievienoto vērtību sapropel̦a izmantošanai būvniecības nozarē, kā ekologiskajam materiālam no vietējiem resursiem.

Sapropelis ar zemu pelnainību un paaugstinātu $\mathrm{NaOH}$ saturu tiek izmantots kā piedeva fasādes māla ķieǵel̦u izgatavošanā. Sapropeḷa sārms un tā veidotā reducējošā vide paaugstina stikla fāzes saturu keramikas izstrādājumos un ir kā indikators par izbalējumu veidošanos ķieǵel̦a virspusē [87].

Teorētiski sapropelis der serdeṇu un tapsējuma maisījumu gatavošanā lietuves rūpniecībā. Daudzu iegulu sapropel̦a fiziski mehāniskās īpašības un ķīmiskais sastāvs der formēšanas maisījumu izstrādei. Sapropel̦a serdenu maisījumiem ir labas mehāniskās īpašības, zema higroskopija un to mais̄̌šanai ir nepieciešams ievērojami mazāks laiks. Sapropel̦a tapsējumu maisījumu pētījumi Minskas traktoru rūpniecībā uzrādīja, ka tas ir labs formēšanas materiāls, kas nodrošina augstas kvalitātes lējumus [87].

Lopbarības efektivitātes paaugstināšana ar sapropeḷa maisījumiem tika plaši pētīta Lietuvā un Baltkrievijā 20. gadsimta otrajā pusē. Sapropel̦a lopbarības piedevas uzlabo dzīvnieku aknu un kunggu darbību, asins veidošanos un cirkulāciju, samazina saslimšanas gadījumus un paaugstina dzīvnieku noturību pret nelabvēlīgiem vides apstākliem [20].

Organiskais sapropelis tiek uzskatīts par vienu no vērtīgākajiem praktiskās izmantošanas ziṇā, jo tas satur daudz olbaltumvielas, vitamīnus, fermentus un citas biologiski aktīvas vielas, taču Lietuvā veiktie pētījumi uzrādīja, ka praktiski visus sapropel̦a veidus var izmantot lopbarības piedevās. Pašlaik popularitāti gūst sapropel̦a humusvielu lopbarības piedevas, piemēram, nātrija humāts. Šie preparāti uzlabo oksidēšanas procesus organismā - palīdz paaugstināt un uzkrāt olbaltumvielas asin̄̄s, paaugstina eritrocītu veidošanos sarkanajās kaula smadzenēs, uzlabo A un citu vitamīnu sintēzi, normalizē vielmaiņu un ir efektīvs toksikozes ārstēšanā.

Šo resursu var izmantot arī kā lēto kurināmo - veidot no tā granulas vai briketes dz̄ivojamo māju un palīgēku apsildīšanai. Krievu zinātnieki piedāvāja ar sapropeli piln̄̄gi aizvietojot ogḷu kurināmo aglopirīta (siltumizolējošais materiāls) ražošanai, no kura var iegūt dažādas siltumizolējošas konstrukcijas un vieglo betonu (marka 300 - 500), kura ražošanai ir nepieciešami lieli cementa apjomi [27].

Jāatzīst, ka derīgo izrakteņu resursu vienkārša sadedzināšana krāsn̄̄ nav racionālākais to izmantošanas veids, ņemot vērā to faktu, ka Latvijas sapropelis pēc tā ķīmiskajiem rādītājiem pieskaitāms pie augstas kvalitātes klases.

1935. gadā B. Kḷimovs bija pirmais, kurš atzīmēja, ka sapropel̦a ķīmiskā pārstrādē var iegūt tos produktus rūpniecībā, kurus nevar iegūt no cita kurināmā. Īpaši viņš atzīmēja fenolus, motoru degvielas, mīkstinātājus gumijas rūpniecībā un sapropel̦a organiskās bāzes, kuru saturs sapropel̦a pirmdarvā ir lielāks nekā citu kurināmo darvā.

Sapropelis ar pelnainību 20 - 35\% ir vērtīga un vispusīga izejviela ķīmiskai pārstrādei. No tā var iegūt bitumus, lielumolekulāras karbonskābes, šksidrās degvielas un eḷıas, parafīnu, fenolu, piridīnskābes, elektroizolācijas materiālus, gumijas mīkstināšanas līdzekḷus, amonija savienojumus un citus produktus.

Latvijā veiktie pētījumi uzrādīja, ka no vietējā sapropeḷa puskoksnēšanas laboratorijas apstākḷos var iegūt $20-38 \%$ pirmdarvas no tā kopsausnes, kas satur 2/3 neitrālo sastāvdaļu un ir piemērota izejviela šķidro degvielu, el̦lu un parafīna iegūšanai. No 1 t sausa sapropel̦a masas ar pelnainību $10-$ $20 \%$ koksēšanas procesā tika iegūts (\% sausne) 350 - $450 \mathrm{~kg}$ koksa, 79 - $100 \mathrm{~kg}$ šķidrā kurināmā, 20 - $25 \mathrm{~kg}$ parafīna, 10 $15 \mathrm{~kg}$ piridīna, $7-8 \mathrm{~kg}$ škīininātāja (metanols + acetons) un $10 \mathrm{~kg}$ amonija vai $30 \mathrm{~kg}$ amonija sulfāta mēslojumam [33].

XIX gadsimta beigās parādās pirmās publikācijas, kurās tiek aprakstīta sapropeḷa labvēlīgā ietekme, ārstējot reimatismu un kaulu plēves iekaisumus [27].

Sapropel̦a augstā siltumietilpība nodrošina ilgstošu un dziḷu audu sildīšanu un normalizē asinsspiedienu, kas sekmē 
locītavu, perifērās nervu sistēmas, ādas un sieviešu dzimumorgānu iekaisumu ārstēšanu. Augsta sapropel̦a adsorbcijas spēja stimulē slapju, plēstu brūču apžūšanu. Antibiotikas un antioksidanti sapropelī sekmē ātru iekaisuma procesu izbeigšanos, ārstē ekzēmas, dermatītu un apdegumus. Ar uzsildīta sapropeḷa aplikācijām sekmīgi tiek ārstēti flegmoni (difūzais tauku šūnaudu iekaisums ar strutu veidošanos), mastīti, furunkuli, hroniski gastrīti, čūlu izraisītas kungga un divpadsmitpirkstu zarnas slimības, jo tie stimulē fagocītu (šūnas, kas spēj iznīcināt organismā iekḷuvušos svešksermeņus un baktērijas) aktivitāti, kuru darbības rezultātā notiek intensīva audu reǵenerācija [27].

Tāpat kā medicīnā, sapropelis plaši tiek lietots veterinārijā. Sekmīgi šajās jomās tiek ārstētas ārējo un iekšējo audu iekaisumu slimības: metrīts (uroǵenitālā trakta iekaisums), mastīts (krūts dziedzera iekaisums), bursīts (gḷotsomiñas iekaisums), flegmons, tendovaginīts (cīpslas maksts iekaisums), dažāda veida abscesi u.c., tiek ārstētas arī daudzu slimību hroniskās formas [27].

Protams, ārstniecisko dūņu ražošanai neder jebkurš sapropelis. Šim nolūkam stingras prasības ir izstrādātas tikai Baltkrievijā (sk. 4.tabula).

Zinātnieki, kas pētīja sapropel̦a ķīmiskās pārstrādes iespējas, apgalvoja, ka sapropelis ar augstu mineralizācijas pakāpi, kas k̦īmiskajā pārstrādē un medicīnā ir maz piemēroti, var tikt izmantoti lauksaimniecībā kā mēslošanas līdzeklis, jo tas satur visus augiem nepieciešamos barības elementus un mikroelementus [22], [33].

Mūsdienās mēslojumam izmanto visu veidu sapropeli, kurus nosacīti var iedalīt trīs grupās [27]:

1. grupa - sapropelis ar organisko vielu saturu virs $50 \%$, tiek izmantots organiski minerālos mēslojumos. Kompostējot tādu sapropeli nav nepieciešama dažādu organisko materiālu (kūdra u.c.) pievienošana;

2. grupa - sapropelīti ar organisko vielu saturu no $10 \mathrm{lī} d z$ $50 \%$. Tie ir sarežǵīti minerāli mēslojumi, kas ir bagāti ar kalıki, fosforskābi, kopējo slāpekli un organiskām vielām;

3. grupa - mineralizēti nogulumi ar organisko vielu saturu līdz 10\% pārsvarā tiek izmantoti augsnes mehāniskā sastāva uzlabošanai. Ja šajos nogulumos ir liela $\mathrm{CaO}$ koncentrācija, tas samazina augsnes skābumu.

Latvijā labi panākumi, lietojot sapropeli augsnes mēslošanā, 1954 - 1955. gadā bija iegūti Bulduru Dārzkopības tehnikumā [33]. 1954. gadā mēslošanas izmēgeinājumi ar „Spīgu” sapropeli tika veikti tehnikuma mācību saimniecībā. Jūrmalas vieglā smilts augsnē tika stādīti kartupel̦i, kāposti un burkāni (sk. 5.tabula).

Pielietojot „Spīgu” sapropeli trūdzemes podinos, aizvietojot trūdzemi ar sapropeli, 1954. gadā agro kāpostu dēsts sapropeḷa podin̄os attīstījās daudz spēcīgāks nekā parastajos trūdzemes podinos.

1955. gadā Bulduru dārzkopības tehnikuma mācību saimniecības izmēginājumos tika izlietots Lielupes attekā iegūts sapropelīts ar aptuveni $25 \%$ organisko vielu kā mēslojums burkāniem, kartupel̦iem un gurķiem. Salīdzinot ar kontroles paraugiem sapropelīts palielināja burkānu ražu par $40 \%$, kartupel̦u - par $41 \%$ un gurksu ražu par $60 \%$.

$$
\text { 4. TABULA }
$$

PRASĪBAS SAPROPEḶA IZMANTOŠANAI ĀRSTNIECISKO DŪṆU RAŽOŠANĀ [91]

\begin{tabular}{|c|c|}
\hline Sapropeḷa īpašība & Norma \\
\hline \multicolumn{2}{|l|}{ Ārējās pazīmes } \\
\hline krāsa & $\begin{array}{l}\text { viendabīga, no pelēcīgas līdz } \\
\text { melnai }\end{array}$ \\
\hline smarža & nav vispār vai sērūdeņraža \\
\hline konsistence & viskoza, plastiska \\
\hline ieslēgumi & $\begin{array}{l}\text { var saturēt nepilnīgi sadalījušās } \\
\text { veidotājaugu šksiedras, nedrīkst } \\
\text { atrasties gliemežvāki un čaulas }\end{array}$ \\
\hline \multicolumn{2}{|l|}{ Vispārējās pazīmes } \\
\hline Mitrums, (\%) & $80-90$ \\
\hline Pelnu saturs, $(\%)$ & $\leq 50$ \\
\hline $\mathrm{pH}$ & $4,5-8,0$ \\
\hline $\begin{array}{l}\text { Daļin̦as lielākas par 0,2 mm, (\% sausas } \\
\text { masas) }\end{array}$ & $\leq 20$ \\
\hline Stingrības robežspriegums, $(\mathrm{Pa})$ & $200-800$ \\
\hline Kopējā dūṇu šķīdības mineralizācija, (g/l) & $<2$ \\
\hline \multicolumn{2}{|l|}{ Sanitāri bakteriologisiski rādītāji } \\
\hline Koli titrs & $\geq 1,0$ \\
\hline Clostridium perfringens titrs & $\geq 1,0$ \\
\hline Staphylococcus un Streptococcus & nedrīkst atrasties \\
\hline $\begin{array}{l}\text { Clostridium (stingumkrampjus izraisoša } \\
\text { nūjiņveida baktērijas) }\end{array}$ & nedrīkst atrasties \\
\hline
\end{tabular}

5. TABULA

„SPĪGU” SAPROPEĻA IETEKME UZ DĀRZEN̦U RAŽU [33]

\begin{tabular}{|l|l|l|l|}
\hline Kultūra & Mēslojums & Raža, (cnt/ha) & Raža, (\%) \\
\hline \multirow{4}{*}{ Kartupeḷi } & Kontrole & 207 & 100 \\
\cline { 2 - 4 } & Kūtsmēsli (30 t/ha) & 255 & 123 \\
\cline { 2 - 4 } & „Spīgu” sapropelis (30 t/ha) & 334 & 160 \\
\cline { 2 - 4 } & Lielupes sapropelīts (30 t/ha) & 292 & 141 \\
\hline \multirow{3}{*}{ Kāposti } & Kontrole & 360 & 100 \\
\cline { 2 - 4 } & Kūtsmēsli (30 t/ha) & 580 & 160 \\
\cline { 2 - 4 } & „Spīgu” sapropelis (30 t/ha) & 630 & 175 \\
\hline \multirow{3}{*}{ Burkāni } & Kontrole & 441 & 135 \\
\cline { 2 - 4 } & Kūtsmēsli (30 t/ha) & 595 & 140 \\
\cline { 2 - 4 } & „Spīgu” sapropelis (30 t/ha) & 618 & 100 \\
\cline { 2 - 4 } & Lielupes sapropelīts (30 t/ha) & 618 & \\
\hline
\end{tabular}

Sapropel̦a norma augsnes ielabošanai ar sapropeli ir $10-$ 150 t/ha un galvenokārt ir atkarīga no augsnes īpašībām, sapropel̦a tipa un kultivētiem augiem.

Racionālākais sapropel̦a izmantošanas veids būtu kombinēt sapropel̦a izmantošanu rūpniecībā un lauksaimniecībā. Vērtīgāko sapropeli būtu lietderīgāk izmantot ķīmiskajā rūpniecībā, bet vairāk mineralizēto - lauksaimniecībā. 


\section{LITERATŪRAS SARAKSTS}

[1] Leinerte, M.. Ezeri deg! Rīga : Zinātne, 1988. 94 lpp.

[2] [Anonīms]. Latvijas PSR Kūdras fonds uz 1980. gada 1. janvāri. Rīga : Latvijas Valsts Meliorācijas projektēšanas institūts, 1980.716 lpp.

[3] Latvijas zemes dzīlu resursi. Seglinšs, V., Brangulis, A.J. (red.) Rīga : Valsts geologijas dienests, 2001. 32 lpp.

[4] Latvijas PSR üdenstilpju sapropę̧a nogulumi. N. Brakš, L. Dubova, I. Brakšs, K. Logina. Rīga: Zinātne, 1967. 80 lpp. (krievu val.).

[5] Liuținas, R., Jankevičius, K., Šalkauskas, M., et al. Improvment of Lake Sapropel Quality: A New Metod. Geografijos metraštis, 2005, vol. 38, N 2, p. 44-51

[6] Emeis, K.C. Sapropel. In: Encyclopedia of paleoclimatology and ancient environments. Springer, Dordrecht, 2009. p. 875-877. http://dx.doi.org/10.1007/978-1-4020-4411-3 204

[7] Korde, N. Krievu sapropelu biostratifikācija un tipologija. Maskava : PSRS Zinātņu Akadēmijas izdevniecība, 1960. 220 lpp. (krievu val.).

[8] Lācis, A. Sapropelis Latvijā. Latvijas Universitātes 61. zinātniskā konference, Rīga, Latvija. Referāts. [skatîts 06.05.2013.]. Pieejams: http://www.ezeri.lv/blog/DownloadAttachment?id=666

[9] Küdras fizika un ķ̄īmija: Mācību līdzeklis augstskolām. I.I. Lištvan, E.T. Bazin, N.I. Gamajunov, A.A. Torentjev. Maskava : Nedra, 1989. 304 lpp. (krievu val.).

[10] Lundquist, G. Bodenablagerungen und Entwicklungstypen der Seen. Die Binnengewässer, 1927, Bd.2, p. 1-119.

[11] Titov, E. Par Urālas sapropę̣a pigmentiem. Sapropeļa nogulumu laboratorijas darbi. 1950, Nr.4, 114-119 lpp. (krievu val.).

[12] Kirejčeva, L., Hohlova, O. Sapropeļi. Sastāus, īpašǐbas, izmantošana. Maskava : Roma, 1998. 120 lpp. (krievu val.).

[13] Tomin, E.D., Fomin, A.I. Sapropelis, tāa ieguve un izmantošana lauksaimniecībā. Jaroslavska : Verhne - Volžskoe, 1964. 104 lpp. (krievu val.).

[14] Pārskats par ezeru sapropeļu atradņu meklēšanas darbiem. Pases sapropeḷa iegulām. Valsts ǵeologijas fonds, 1990-2000.

[15] Kurzo, B.V. Kaustobiolīiti un ekolog̣ija. Küdras rūpniecība, 1989, Nr.2, 120-126 lpp. (krievu val.).

[16] Kurzo, B.V., Gaidukēvič, O.M., Žukov, V.K. Baltkrievijas sapropeḷa genēzes, resursu un iegulu apgūšanas pētījumi. Dabas saimniecība, 2012, Nr.22, 57-66 lpp. (krievu val.).

[17] Pidoplizko, A.P., Grišuk, R.I. Daži rezultāti no Baltkrievijas PSR sapropę̧a nogulumu pētijumiem. Küdras un sapropeļa ķīmija un genēze, 1962, 258-274 lpp. (krievu val.).

[18] Pidoplizko, A.P. Baltkrievijas PSR ezeru nogulumi. Minska : Zinātne un tehnika, 1975. 120 lpp. (krievu val.).

[19] Lopotko, M.Z. Baltkrievijas PSR sapropeļi, to ieguve un izmantošana. Minska : Zinātne un tehnika, 1974. 208 lpp. (krievu val.).

[20] Jevdokimova, G., Bukač, O., Tiškovič, A., u. c.. Sapropeḷu minerālo komponentu agrokīimiska nozīme. BPSR ZA Vesc. 1980, Nr.4, 38-42 lpp. (krievu val.).

[21] Lopatin, N.V. Degizrakteņu veidošanās. Maskava : Nedra, 1983. 192 lpp. (krievu val.).

[22] Brakš, N.A. Sapropela nogulumi un to izmantošanas veidi. Rīga : Zinātne, 1971. 282 lpp. (krievu val.).

[23] Sten, E., Thybo, H., Noe-Nygaard, N. Resistivity and georadar mapping of lacustrine and glaciofluvial sediments in the late- glacial to postglacial Store Amose basin, Denmark. Bulletin of the Geological Society of Denmark, 1996, vol. 43, p. 87-98.

[24] Kulkova, M., Mazurkevich, A., Dolukhanov, P. Chronology and paleoclimate of prehistoric sites in western Dvina - Lovat area or North - Western Russia. Geochronometria, 2001, vol. 20, p. 87-94.

[25] Janbu, A.D., Paasche, Ø.P., Talbot, M.R. Paleoclimate changes inferred from stabule isotopes and magnetic properties of organic - rich lake sediments in Arctic Norway. Journal of Paleolimnology, 2011, vol. 46, p. 29-44. http://dx.doi.org/10.1007/s10933-011-9512-2

[26] Forel, F.A. La limnologie, branche de la Geographie. Comptes Rendue Du Sixième Congres International de Geographie, 1895, p 1-4.

[27] Štin, S.M. Ezeru sapropeļi un to kompleksā apgūšana. Maskava: Maskavas Valsts kalnrūpniecības universitāte, 2005. 373 lpp. (krievu val.).

[28] Cranwell, P. Environmental organic chemistry of rivers and lakes, both water and sediments. Environmental Chemicals, 1975, vol. 1, p 22-54.

[29] Golterman, H.L. The chemistry of Phosphate and Nitrogen Compounds in Sediments. Dordrecht: Kluwer Academic Publishers, 2004. 284 p.
[30] Largin, I.F. Kūdras un sapropeḷa iegulu īpašības un izpētes metodes. Rakstu krājums. Tver: Kaḷiņinas Valsts universitāte, 1983, 27-53 lpp. (krievu val.).

[31] Dmitrieva, E. D. Belgorodas apgabala sapropela kīmiskais sastāvs un biologiska aktivitāte. Disertācija. Sanktpēterburga: Tulas valsts pedagogiska universitāte, 2003. 233 lpp. (krievu val.).

[32] Potenje, G. Sapropelīti. Petrograde : Naftas un slānekḷu saimniecība, 1920. 212 lpp. (krievu val.).

[33] Vimba, B. Sapropeḷa termiskā šķ̄īināāšana un iegūto produktu ķ̄imiskais raksturojums. Disertācija. Rīga: Latvijas Lauksaimniecības Akadēmija, 1956. $170 \mathrm{lpp}$.

[34] Kazakov, E. Saldūdens sapropeļu genēze un ķīmiskais raksturojums. Degizrakteņu institūta raksti, 1950, Nr.2, 253-266 lpp. (krievu val.).

[35] Konoiko, M. Par ezeru un purvu veidošanos Baltkrievijā. ezeru vēsture. Saldūdens ezeru pamatproblēmu Vissavienības simpozija raksti, 1970, Nr.2, 56-67 lpp. (krievu val.).

[36] Lopotko, M.Z., Kislov, N. Sapropeļa izmantošana tautsaimniecībā PSRS un ārvalstīs. Minska : Zinātne un tehnika, 1990. 85 lpp. (krievu val.)

[37] Horne, A., Goldman, C.. Limnology. 2nd edition. New York : McGraw-Hill Co, 1994. 576 p.

[38] Bloesch, J. Sedimentation and Lake Sediment Formation. In: The Lakes Handbook: Limnology and limnic ecology. O'Sullivan, P.E. \& Reynolds, C.S. (eds.). A Blackwell Publishing company, 2005, vol. 1, p. 197-229.

[39] Niessen, F., Sturm, M. Die Sedimente des Baldeggersees (Schweiz): Ablagerungsraum und Eutrophierungsentwicklung der letzten 100 Jahre. Archiv für Hydrobiologie, 1987, Bd. 108, p. 365-378.

[40] Stabel, H. Mechanisms controlling the sedimentation sequence of various elements in prealpine lakes. In: Chemical Processes in Lakes. New York : Wiley, 1985, p. 143-167.

[41] Allen, A.A., Allen, J.R. Basin analysis: principles and applications. 2nd edition. Malden : Blackwell Publishing Ltd, 2005. p. 560.

[42] Nikolajev, D.. Karbonātu - hāru sapropelis: ķīmiska struktūra un biologiska aktivitāte. Disertācija. Maskava : Maskavas Valsts universitāte, 2003. 161 lpp. (krievu val.).

[43] Bronštein, Z. Saldūdeņu Ostrecoda. Vē̌̌veidīgie. PSRS fauna, sēj.2, Nr.1. Maskava : PSRS Zinātnuu Akadēmija, 1941, 340 lpp. (krievu val.).

[44] Kazakov, E., Proṇina, M. Dažādas formas planktona un bentosa ķīmiskais sastāvs. Sapropeļa genēzes laboratorijas raksti, 1941, Nr.2, 49-57 lpp. (krievu val.).

[45] Lopotko, M., Jevdokimova, G., Bukač, O. u. c. Baltkrievijas PSR sapropeļa nogulumu kadastrs 6-os sējumos. Minska : Zinātne un tehnika, 1983, 118 lpp. (krievu val.).

[46] Golterman, H., Clymo, K., Clymo, R. Physiological limnology. Amsterdam : Elsevier Scientific Publishing Company, 1975. 480 p.

[47] Butz, S.D. Science of Earth System. 2nd edition. New York : Thomson Delmar Learning, 2002. 655 p.

[48] Juday, C. The summer standing crop of plants and animals in four Wisconsin lakes. Transactions of the Wisconsin Acadademy Science, Arts and Letters, 1942, vol. 34, p. 103-135.

[49] Agrawal, S.C. Limnology. New Delhi: A.P.H. Publishing, 1999. 150 p.

[50] Closs, G., Downes, B. \& Boulton, A. Freshwater ecology: a scientific introduction. Malden [etc.], A Blackwell Publishing company, 2004. $204 \mathrm{p}$.

[51] Moriarty, D.J.W., Pullin, R.S.V. (eds.) Detritus and Microbial Ecology in Aquaculture. Manila : International center for living aquatic resources management, $1987.425 \mathrm{p}$.

[52] Perfịjjev, B. Dūṇaino ezeru nogulumu mikrozonālā uzbūve un to pētījumu metodes. Zinātne, 1972, 6-16 lpp. (krievu val.).

[53] Ș Șapnikov, D.S., Demuk I.G., Okuṇev P.V. Urālas ezera nogulumu minerālie komponenti. Sverlovska : Urālas Valsts universitāte, 1990. 104 lpp. (krievu val.).

[54] Bakšeev, V.N. Sapropelis vakar, šodien un rīt: monogräfija. Tjumen̦a : Reǵionāla informacionāla aǵentūra, 1998. 80 lpp. (krievu val.).

[55] Ponomareva, M.A. Tatarstānas sapropeļa ķ̄imiskais sastāvs un izmantošanas virzieni. Disertācija. Tula : Tulas valsts pedagoǵiska universitāte, 2002. 245 lpp. (krievu val.).

[56] Kurmiševa, N.A. Sapropeļa mēslojumu ietekme uz humusu stāvokli velēnu gleja un velēnu podzolangsnēm. Disertācijas kopsavilkums. Maskava : Maskavas Valsts universitāte, 1988. 20 lpp. (krievu val.).

[57] Filippov, J.N., Taraskina, D.V., Žuraṿ̣ov, A.I. Dažu peloīdu organiskas frakcijas antioksidējošais mehānisms. Kurortologijas jautājumi., 1969; Nr.1, 17-21 lpp. (krievu val.). 
[58] Poznjak, V., Rakovskij, V. Baltkrievu PSR sapropeḷa organiskas masas k̦īmiskais sastāvs. Küdras un sapropeḷa ķīmija un genèze, 1962, 298308 lpp. (krievu val.)

[59] Orlov, D., Birjukova, O., Suhanova, N. Krievijas Federācijas augšṇu organiskas vielas. Augsnes zinātne, 1996, Nr.2, 197-207 lpp. (krievu val.).

[60] Goncov, A., Ložeņicina, V. Dažādu sapropeḷu īpašības. Cietās degvielas ķīmija, 1984, Nr.1, 67-74 lpp. (krievu val.).

[61] Lištvan, M., Lopotko, M. Sapropeḷa izmantošana tautsaimniecībā. Sapropeḷa izmantošanas problēmas tautsaimniecībā, 1976, 5-13 lpp. (krievu val.).

[62] Karpukhin, A. Complex Compounds of Humic Substances with heavy Metals. Eurasian Soil Science, 1998, vol. 31, N 7, p. 764-771.

[63] Shinkarev, A., Lyutakhina, N., Gnevashov, S. Separation of the groups of humic substances upon recurrent treatment with Solvents. Eurasian Soil Science, 2000, vol. 33, N 7, p. 709-712.

[64] Kirejčeva, L., Hohlova, O. Sapropelu nogulumu humusvielu elementu sastāvs. Augsnes zinātne, 2000, Nr.9, 1-376 lpp. (krievu val.).

[65] Lopotko, M., Jevdokimova, G., Kuzmickij, P. Sapropeli lauksaimniecībā. Minska : Zinātne un tehnika, 1992. 215 lpp. (krievu val.).

[66] Rakovskij, V.E., Edelštein, N. Fenolu sadalīšana ar fenolāta frakcionētu neitralizācijas metodi. Küdras institūta raksti, 1939, Nr.19. 102-133 lpp. (krievu val.).

[67] Dunning, H.N. Geochemistry of organic pigments. In: Organic geochemistry. Breger, I.A. (edt). New York : Pergamon Press, 1963, p. $367-430$.

[68] Hajibrahim, S., Tibbetts, P., Watts, C., et al. Analysis of carotenoid and porphyrin pigments of geochemical interest by high-performance liquid chromatography. Analytical chemistry, 1978, vol. 50, N 4, p. 549-553. http://dx.doi.org/10.1021/ac50026a004

[69] Trask, P., Wu, C. Does Petroleum form in sediments at time of deposition. Bulletin of the American Association of Petroleum Geologists, 1930, vol. 14, p. 1451-1463.

[70] Anderson, P., Vimba, B. Karotīna saturs un biologiskā vērtība Latvijas sapropeḷosa. Sverlovskas lauksaimniecības institūta raksti, 1968, sēj.17, 17-24 lpp. (krievu val.).

[71] Lederer, E. Carotenoids of the cryptogams. Bullettin Societas Chimie at Biologiae, 1938, vol. 20, p. 611-634.

[72] Karrer, P., Jucker, E. Carotenoids. New York : Elsevier Publishing Company, $1950.384 \mathrm{p}$

[73] Vallentyne, J. Carotenoids in a 20,000-year-old sediments from Searles Lake, California. Archives of Biochemistry and Biophysics, 1957, vol. 21 , p. $245-250$.

[74] Fox, D., Anderson, L. Pigments of marine muds. Proceedings of the National Academy of Sciences of the United States of America, 1941, vol. 27, p. 333-337. http://dx.doi.org/10.1073/pnas.27.7.333

[75] Lopotko, M., Jevdokimova, G. Sapropeli un produkti uz to bāzes. Minska : Baltkrievijas PSR Zinātṇu akadēmija, 1986. 61 lpp. (krievu val.).

[76] Stepanova, E. Sapropeļu huminskābju ķīmiskās īpašības un uzbūve. Disertācija. Maskava : Maskavas Valsts universitāte, 1996. 101 lpp. (krievu val.).

[77] Letunova, S.V. Dažāa veidu aktinomicētu un baktêriju, kas izdalītas no kobalta bioḳīmiskām provincēm, vitamīna B12 veidošana. Mikrobiologija, 1958, sēj.27, Nr.4, 1-12 lpp. (krievu val.).
[78] Pakarskite, K., Konopkajte, S., Dačulite, J. Vitamīna B12 likumsakarīgs izvietojums sapropeḷa nogulumos Lietuvas ezeros un riboflavīna, folijskābes un tiamīna saturs tajos. Sverlovskas lauksaimniecības institūta raksti, 1962, Nr.10, 193-200 lpp. (krievu val.).

[79] Kazak, V.A., Provotorov, S.I., Tabakov, N.A., u. c. Sapropela izmantošanas rekomendācijas lopkopībā un putnkopībā. Krasnojarska, 1975. (krievu val.).

[80] Verzilin, A. Vispārīgas likumsakarības ezeru veidošanā un attīstībā. Ezeru vēstures izpētes metodes, 1986, sērija: PSRS ezeru vēsture, 57-63 lpp. (krievu val.).

[81] Fedotov, A. Sapropeḷu mikroelementu sastāvs. Sapropeļa izmantošanas problèmas tautsaimniecībā, 1976, 97-104 lpp. (krievu val.).

[82] Kuzñecov, S. Ezeru mikrofloras un tās geokìmiska darbība. L,eningrada : Nauka, 1970. 440 lpp. (krievu val.).

[83] Marčenko, L., Kapuḷnikova, Z. Baltkrievijas ezeru sapropeḷu mikrobiologiski pētījumi. Sapropela izmantošanas problēmas tautsaimniecībā, 1976, 74-81 lpp. (krievu val.).

[84] Sturis, T. Kañiera un Babītes ezera sapropeḷa dūņu mikrofloras pētījumi. Disertācijas kopsavilkums. Rīga : Latvijas eksperimentālas un klīniskas medicīnas institūts, 1965. (krievu val.).

[85] Kurzo, B.V. Sapropeļa veidošanās un izmantošanas problēmu likumsakarības. Minska: Bel.nauka, 2005. 224 lpp. (krievu val.).

[86] Humātu reaǵenti. Kalnrūpniecības enciklopēdija. [Skatīts 19.12.2013]. Pieejams: http://www.mining-enc.ru/g/gumatnye-reagenty/

[87] Širokov, V.A. Slānsecīga sapropeļa ieguve un tā izmantošana Pieamūras apūdeņotās zemēs. Disertācija. Blagoveščenska: Tālo Austrumu Valsts agrārā universitāte, 2003. 182 lpp. (krievu val.).

[88] Brakšs, N., Miḷins, N. Pētījumi par sapropeḷa kompleksas izmantošanas iespējām ar hidrolīzes un saustvaices metodi. LLA raksti, 1960, Nr. IX. 471 - 479.lpp. (krievu val.).

[89] Gružāāns, A. Sapropel̨betons. LLA raksti, 1960, Nr.9, 547 - 561.lpp.

[90] Gružāns, A. Sapropeḷbetons. Latvijas PSR Zinātņu Akadēmijas vēstis, 1958, Sēj.12, Nr.137, 163 - 170.1pp.

[91] Sapropeļa ārstnieciskā dūņas. Baltkrievijas Republikas tehniskie noteikumi 100217946.001-2000. 12 lpp. (krievu val.).

Karina Stankeviča: Mg.sc.env., Ph.D. student in Environmental Science at the University of Latvia, Faculty of Geography and Earth Science. Professional Bachelor of Landscape Architecture and Planning, Latvian University of Agriculture in 2009. Master degree in Environmental Science earned at the University of Latvia in 2011. The major field of study: water objects in landscape, limnic freshwater ecosystem, lake's organic rich sediments properties and possibilities of use, humic substances.

Address: University of Latvia, Raina bulv. 19, LV-1586, Riga, Latvia.

E-mail: karina.stankevica@lu.lv

Māris Kḷaviņš: Dr.hab.chem., Professor at the University of Latvia, Faculty of Geography and Earth Sciences, Department of Environmental Sciences. M. Kḷaviņš obtained his scientific degree in chemistry of biologically active compounds at the Moscow State University in 1986, but a habilitation degree at the University of Latvia in 1994. He is a member of Academy of Sciences of Latvia, coordinator of International Humic Substances Research Society (IHSS). Research interests are related to studies of natural organic matter, wetlands and bogs and environmental pollution problems.

Address: University of Latvia, Rainga bulv. 19, LV-1586, Riga, Latvia.

\section{Karina Stankeviča, Māris Kḷaviņš. Sapropel and Its Application Possibilities}

The aim of the paper is to consider sapropel classification, formation, properties and possibilities of use. Theoretical framework of the research is established by analysing literature on sapropel. Sediments accumulate during the lake existence period and they are formed from the remains of organisms living in the lake and its surroundings, and mineral material supplied to the lake from the catchment area and atmosphere. In the freshwater bodies located in the temperate forested areas, usually sediments with high organic matter content (over 15\%) are formed from aquatic plants, mainly fresh water algae, plankton and benthic organisms and transformed under influence of bacteria, and mixed with mineral components. Sapropel has a finely dispersed and plastic structure; the colour - from light pink to dark brown. Usually sapropel is divided into four big types: organic, silicate, carbonatic and mixed. Each sapropel type is subdivided. Latvia has 2256 lakes with a total area of $1001 \mathrm{~km}^{2}$ or $1.5 \%$ of the country. The total area of mires is $6401 \mathrm{~km}^{2}$ or $9.9 \%$ of Latvia. Most lakes and bogs contain sapropel deposits. The State Geology Office of Latvia states that there are more than 750 million $\mathrm{m}^{3}$ of lake sapropel resources and about 1.5 billion $\mathrm{m}^{3}$ of sapropel reserves. There are about 2 billion $\mathrm{m}^{3}$ of joint sapropel resources in Latvia. It is suggested that sapropel can be used in various fields. In some countries, for instance, in Russia, Byelorussia and Ukraine, sapropel is used in balneology, livestock farming, agriculture, cosmetology and other fields. However, nowadays the products made on the basis of peat are more popular; therefore, the studies of the organic sediments of lakes are rare. 
$2013 / 29$

Карина Станкевича, Марис Клявиньш. Сапропель и возможное его использование

Целью обзорной статьи является оценка классификации сапропеля, его формирования, состава и возможного использования. Теоретической основой работы являлся литературный обзор оценки знаний о сапропеле в других странах. На протяжении всего существования озера в нем накапливаются донные отложения. Они образуются из остатков живых организмов, живущих в озере и на территории его водосбора. В пресноводных водоемах, расположенных в лесных районах умеренного климата, обычно образуется сапропель - отложения с высоким содержанием органических веществ (более 15\%), которые образуются из останков водных растений, главным образом водорослей, планктона и бентоса, которые преобразуется под влиянием бактерий и смешивается с минеральными компонентами. Сапропель обладает дисперсной и пластичной структурой; цвет от светло-розового до темно коричневого. Обычно выделяют 4 типа сапропеля: органический, силикатный, карбонатный и смешанный. Каждый из типов подразделяется на виды. На территории Латвии насчитывается 2256 озер с общей площадью 1001 км², что является 1,5\% территории страны. Общая площадь болот 6401 км $^{2}$ или 9,9\% территории Латвии. В большей части этих озер и болот можно найти сапропелевые залежи. Замеры геологического фонда Латвии свидетельствуют, что ресурсы озерного сапропеля составляют 750 миллионов м $^{3}$, в болотах - 1,5 миллиарда м³. Общее количество сапропеля в Латвии составляет 2 миллиарда м ${ }^{3}$. Сапропель может быть использован во многих областях народного хозяйства. В таких странах как Россия, Белоруссия и Украина, сапропель используется в бальнеологии, животноводстве, сельском хозяйстве, косметологии и других отраслях народного хозяйства. Однако продукты на основе сапропеля, уступают по популярности продуктам на основе торфа, что объясняется недостаточной изученностью данного ресурса. 